\title{
Mid-crustal shear zone development under retrograde conditions: pressure-temperature-fluid constraints from the Kuckaus Mylonite Zone, Namibia
}

\author{
Johann F. A. Diener ${ }^{1}$, Åke Fagereng ${ }^{1, *}$, and Sukey A. J. Thomas ${ }^{1}$ \\ ${ }^{1}$ Department of Geological Sciences, University of Cape Town, Private Bag X3, Rondebosch 7701, South Africa \\ * present address: School of Earth \& Ocean Sciences, Cardiff University, Cardiff CF10 3AT, UK \\ Correspondence to: Johann F. A. Diener (johann.diener@uct.ac.za)
}

Received: 19 April 2016 - Published in Solid Earth Discuss.: 22 April 2016

Revised: 4 August 2016 - Accepted: 28 August 2016 - Published: 16 September 2016

\begin{abstract}
The Kuckaus Mylonite Zone (KMZ) forms part of the larger Marshall Rocks-Pofadder shear zone system, a $550 \mathrm{~km}$-long, crustal-scale strike-slip shear zone system that is localized in high-grade granitoid gneisses and migmatites of the Namaqua Metamorphic Complex. Shearing along the KMZ occurred ca. $40 \mathrm{Ma}$ after peak granulite-facies metamorphism during a discrete tectonic event and affected the granulites that had remained at depth since peak metamorphism. Isolated lenses of metamafic rocks within the shear zone allow the $P-T$-fluid conditions under which shearing occurred to be quantified. These lenses consist of an unsheared core that preserves relict granulite-facies textures and is mantled by a schistose collar and mylonitic envelope that formed during shearing. All three metamafic textural varieties contain the same amphibolite-facies mineral assemblage, from which calculated pseudosections constrain the $P-T$ conditions of deformation at $2.7-4.2 \mathrm{kbar}$ and $450-$ $480{ }^{\circ} \mathrm{C}$, indicating that deformation occurred at mid-crustal depths through predominantly viscous flow. Calculated $T-$ $M_{\mathrm{H}_{2} \mathrm{O}}$ diagrams show that the mineral assemblages were fluid saturated and that lithologies within the KMZ must have been rehydrated from an external source and retrogressed during shearing. Given that the KMZ is localized in strongly dehydrated granulites, the fluid must have been derived from an external source, with fluid flow allowed by local dilation and increased permeability within the shear zone. The absence of pervasive hydrothermal fractures or precipitates indicates that, even though the KMZ was fluid bearing, the fluid/rock ratio and fluid pressure remained low. In addition, the fluid could not have contributed to shear zone initiation,
\end{abstract}

as an existing zone of enhanced permeability is required for fluid infiltration. We propose that, following initiation, fluid infiltration caused a positive feedback that allowed weakening and continued strain localization. Therefore, the main contribution of the fluid was to produce retrograde mineral phases and facilitate grain-size reduction. Features such as tectonic tremor, which are observed on active faults under similar conditions as described here, may not require high fluid pressure, but could be explained by reaction weakening under hydrostatic fluid pressure conditions.

\section{Introduction}

Crustal-scale deformation is commonly localized into major faults, in the upper crust and ductile shear zones in the lower crust (e.g. Savage and Burford, 1973; Kirby, 1985; Zoback et al., 1985; Scholz, 1988; Wittlinger et al., 1998). This observation requires the presence of weakening mechanisms that both initiate and sustain strain localization into lithospheric high-strain zones (Rutter et al., 2001). Such mechanisms include (1) high fluid pressures, which reduce the effective coefficient of friction and lead to localized and transient embrittlement (Hubbert and Rubey, 1959; Sibson, 1980; Rice, 1992) as well as enhance microfracturing and mass transfer processes (Cox and Etheridge, 1989); (2) grainsize reduction and activation of diffusive mechanisms, particularly in the presence of a reactive fluid phase (Rutter, 1976; Brodie and Rutter, 1987); (3) geometric softening by alignment of easy slip planes and the shear plane, by de- 
velopment of a crystal-preferred orientation (Poirier, 1980; Schmid et al., 1987); (4) reaction weakening by creation of grain-scale porosity (Fusseis et al., 2009) and a fine-grained reaction product (White and Knipe, 1978; Beach, 1980); and (5) introduction of a new, weaker, mineral phase through retrograde reactions, for example the development of an interconnected phyllosilicate fabric (Wintsch et al., 1995; Imber et al., 1997).

The mechanisms listed above are only effective at partitioning strain into a major shear zone if such a localized zone already exists. Shear zone initiation has been linked to the existence of brittle precursors, providing tabular zones of fine-grained material deforming by diffusion creep at highstrain rates with low driving stresses (Mancktelow and Pennacchioni, 2005; Mancktelow, 2006). However, shear zones can also reactivate existing ductile fabrics (Montesi, 2013; Rennie et al., 2013) or initiate through localized reaction softening (Beach, 1980; Holyoke and Tullis, 2006). In a prograde metamorphic setting, it is fairly straightforward to imagine how an existing brittle discontinuity will transform into a ductile shear zone during progressive burial and increased temperature. Similarly, fluid release during prograde dehydration at greenschist facies or above will provide a fluid phase, likely under low-porosity, undrained conditions, which can lead to increased fluid pressure associated with reaction weakening (e.g. Etheridge et al., 1983). On the other hand, in a retrograde metamorphic setting, rocks are not dehydrating, but are fluid absent and capable of rehydration (e.g. Guiraud et al., 2001); therefore a fluid source required for fluid assisted weakening is less obvious (e.g. McCaig, 1988; Oliver, 1996). Similarly, if a shear zone develops within dry, previously migmatized crust under retrograde conditions, there are unlikely to be brittle discontinuities on which a shear zone can initiate (Rennie et al., 2013), unless fine-grained pseudotachylytes have formed through propagation of earthquake ruptures into the viscous regime (Sibson, 1980; Moecher and Steltenpohl, 2009) or local brittle structures formed through fluid-absent, high-stress failure (Andersen et al., 2008) or acceleration within crystal-plastic shear zones (White, 2012). Under retrograde conditions, it is, therefore, not intuitive to envision how initial shear zone weakening occurs, as an external fluid is required for reaction weakening, but requires deformation to be introduced to the site of initiation. It is also not clear what weakening mechanisms remain active through the life of a retrograde shear zone, as elevated fluid pressures are hard to maintain in an open system, but retrograde reactions may lead to the growth of fine-grained products and the formation of new interconnected weak fabrics. We address these questions here by investigating the retrograde metamorphic history of an exhumed, crustal-scale strike-slip shear zone, the Kuckaus Mylonite Zone in southern Namibia, to constrain its pressuretemperature-fluid history and discuss the implications of our results for weakening mechanisms and strain localization.
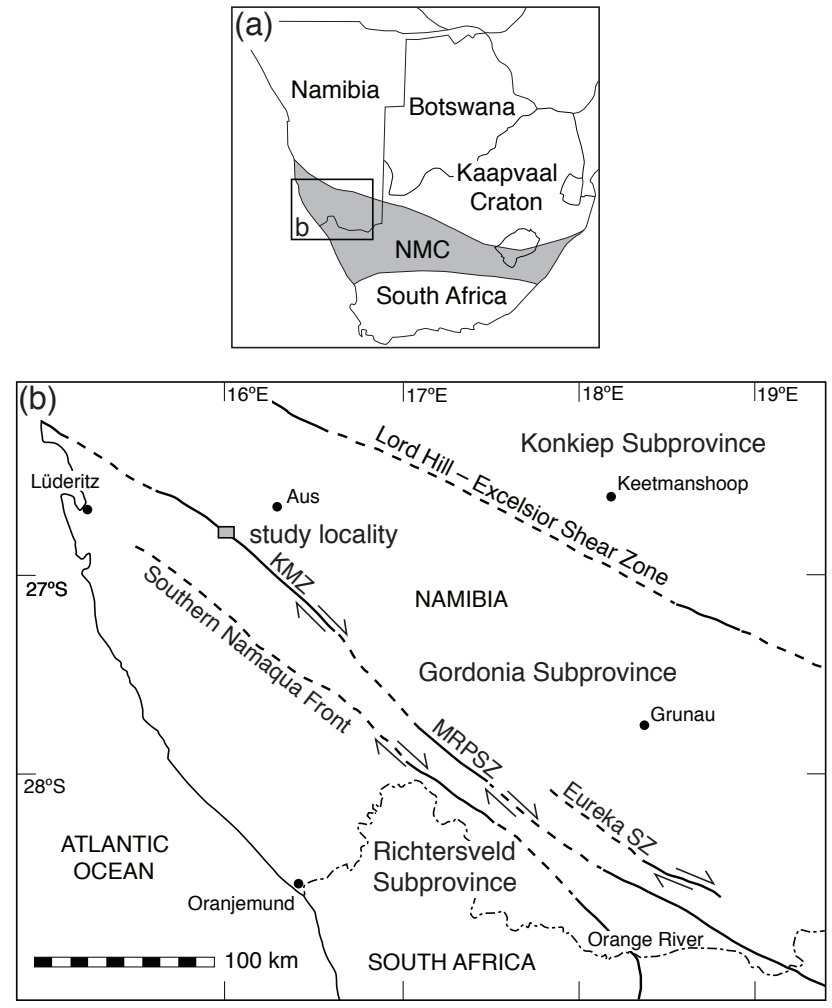

Figure 1. Geological setting of the study area. (a) Map of southern Africa showing the extent of the Namaqua Metamorphic Complex (NMC). (b) Location of the study area to the south-west of Aus in southern Namibia. The Kuckaus Mylonite Zone (KMZ) forms part of the larger Marshall Rocks-Pofadder shear zone (MRPSZ) and has a similar orientation, kinematics and age as the southern Namaqua Front that separates the Richtersveld and Gordonia subprovinces of the NMC and the Lord Hill-Excelsior shear zone that separates the Gordonia and Konkiep subprovinces. After Miller (2008) and Macey et al. (2014).

The problem of fluid flow and localized deformation in ductile shear zones is not restricted to exhumed examples, such as those presented here, but is also a current question of interest in active plate boundaries. For example, the discovery of tectonic tremor and slow slip on the deep extensions of the Alpine and San Andreas faults (Shelly, 2010; Shelly and Hardebeck, 2010; Wech et al., 2012) highlight the presence of localized structures below the brittle-viscous transition. The nature of these seismic signals also require the deep ductile roots of these major faults to be significantly weaker than their surrounding rocks (Shelly, 2010; Shelly and Hardebeck, 2010; Wech et al., 2012). As opposed to similar features in subduction zones, commonly associated with prograde metamorphism and high fluid pressures, the tremors on the deep San Andreas and Alpine faults cannot be easily explained by in situ production of fluids in low-porosity fault zones. It is possible that San Andreas fault tremor is related to retrograde weakening mechanisms associated with the in- 
troduction of an external fluid (Fagereng and Diener, 2011). An additional question to address here is, therefore, how fluid flow and shear zone weakening mechanisms on the Kuckaus Mylonite Zone can serve as an analogue to those occurring on the deep extension of active faults exhibiting tremor and slow slip under retrograde $P-T$ conditions.

\section{Regional and outcrop geology}

The Kuckaus Mylonite Zone (KMZ; first described by Jackson, 1976) forms a segment of the larger Marshall RocksPofadder shear zone system (MRPSZ, after Miller, 2008) that extends for more than $550 \mathrm{~km}$ from the Atlantic coast north of the town of Lüderitz in Namibia to its southern termination near the town of Pofadder in South Africa (Fig. 1; Moen and Toogood, 2007; Miller, 2008). The MRPSZ strikes WNWESE and exhibits a dextral sense of strike-slip displacement (Jackson, 1976; Toogood, 1976; Moen and Toogood, 2007; Rennie et al., 2013). The MRPSZ is localized in mid-crustal rocks of the Namaqua Metamorphic Complex that experienced high-temperature $(T)$-low-pressure $(P)$ amphiboliteto granulite-facies peak metamorphic conditions during the Mesoproterozoic at ca. 1200-1050 Ma (Jackson, 1976; Blignaut, 1977; Waters and Whales, 1984; Waters, 1986, 1988; Robb et al., 1999; Clifford et al., 2004; Cornell et al., 2009; Diener et al., 2013; Diener, 2014; Bial et al., 2015). The development of the MPRSZ post-dates peak metamorphism, with deformation having occurred under retrograde amphibolite- to greenschist-facies conditions, at ca. 1005960 Ma (Jackson, 1976; Toogood, 1976; Rennie et al., 2013; Macey et al., 2014; Melcher et al., 2015). Shearing along the MRPSZ resulted in the development of proto- to ultramylonites, indicating that deformation predominantly occurred by viscous flow of quartz and micas (Toogood, 1976; Moen and Toogood, 2007; Miller, 2008; Rennie et al., 2013; Lambert, 2013); however, a discrete cataclastic overprint indicative of lower-temperature brittle deformation is present in the south-eastern parts of the MRPSZ (Toogood, 1976; Moen and Toogood, 2007; Lambert, 2013; Macey et al., 2014).

In the study area, the KMZ occurs in granitic gneisses that form part of the Aus granulite terrain (Jackson, 1976; Rennie et al., 2013). These rocks experienced peak metamorphic conditions of $5.5 \mathrm{kbar}$ and $825^{\circ} \mathrm{C}$, with the timing of metamorphism constrained at ca. 1065-1045 Ma (Diener et al., 2013). Metamorphism is inferred to have been dominated by heating and cooling, with only minor attendant crustal thickening and burial (Diener et al., 2013). The post-peak metamorphic retrograde path involved near-isobaric cooling, indicating that the terrain remained at depth as it cooled to a stable geotherm (Diener et al., 2013).

The shear zone core of the KMZ is about $1000 \mathrm{~m}$ in width and consists of anastomosing high-strain ultramylonite zones that wrap around lower-strain lozenges (Rennie et al., 2013). Rock types within the KMZ are dominated by granitic gneisses and mylonites, and only minor enclaves and lenses of retrogressed mafic granulite are present. These mafic lenses occur as discrete units, range from a few centimetres to $10-15 \mathrm{~m}$ long and are up to $5 \mathrm{~m}$ in width (Rennie et al., 2013). Larger mafic lenses have a core of coarser-grained gneisses that are not pervasively mylonitized and in which remnant migmatitic granulite-facies textures can be recognized (Fig. 2a). The core is enveloped by more intensely sheared and retrogressed mylonitic schists, with the increase in strain occurring over a distance of $10-50 \mathrm{~cm}$ (Fig. 2b). The fabric in the coarser-grained gneisses and enveloping mylonites has a similar orientation to the penetrative subvertical foliation in the KMZ, and the weakly developed amphibole lineation is parallel to the subhorizontal quartz rodding lineation that is present in the granite gneisses and mylonites (Rennie et al., 2013). Whereas the volumetrically dominant felsic gneisses and mylonites do not contain mineral assemblages that record distinctive $P-T$ conditions, the mafic enclaves provide a record of recrystallization conditions from a preserved migmatitic core to a largely recrystallized mylonitic envelope. Therefore, to constrain the $P-T$-fluid conditions of shear zone deformation, three samples were chosen as a representative section from the core of a low-strain lens, preserving peak fabrics and mineral assemblages, into the well-developed retrograde mylonite zone, and these are described further below.

\section{Petrography and mineral chemistry}

\subsection{Petrography}

The three samples are from the relatively low-strain core of a mafic lens (sample KMZ28), the schistose collar (sample KMZ29) and the mylonitic envelope (sample KMZ30; all collected from $26^{\circ} 48^{\prime} 10^{\prime \prime} \mathrm{S} 015^{\circ} 57^{\prime} 50^{\prime \prime} \mathrm{E}$ ). All three samples are hornblende, plagioclase and quartz-bearing amphibolites and contain variable proportions of additional chlorite, epidote and sphene (Fig. 3). Whereas the similar mineral assemblages and mineral compositions suggest that all three samples were derived from a common protolith, the texture, grain-size and fabric intensity varies dramatically between the samples.

The low-strain sample KMZ28 is coarse-grained and equigranular, with typical grain sizes on the order of $0.2-$ $1 \mathrm{~mm}$ (Fig. 3a). The sample is dominated by hornblende, plagioclase and quartz, with chlorite and epidote only present as subordinate and fine-grained phases on the edges of hornblende and plagioclase (Fig. 3d, e). Hornblende and plagioclase are weakly aligned, giving the sample a poorly developed gneissose fabric. Notably, fine-grained chlorite and epidote do not show a preferred orientation (Fig. 3d, e).

Sample KMZ29 is a medium-grained schist, consisting of elongate hornblende and chlorite-epidote foliae with typical grain sizes on the order of $0.1-0.5 \mathrm{~mm}$ (Fig. 3b). Some horn- 

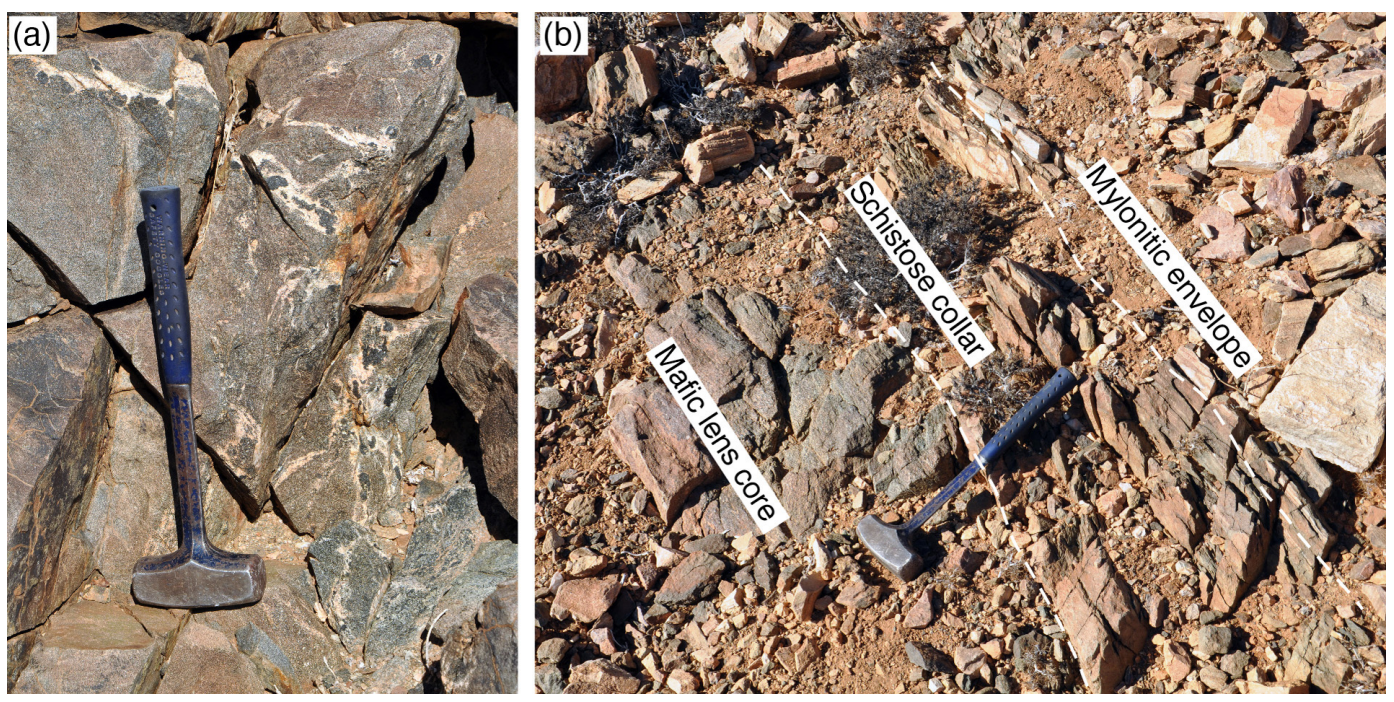

Figure 2. Field photographs of mafic lenses within the KMZ. (a) Detail of the unsheared core of a lens, showing coarse-grained amphibolite with evidence of small-scale migmatization in the form of leucosome stringers and ponds. (b) Boundary of mafic lens showing the increase in strain over a distance of $35 \mathrm{~cm}$. Hammer is $40 \mathrm{~cm}$ long.

blende grains appear to be larger, but are in fact aggregates made up of discrete subgrains (Fig. 3f, g). Chlorite foliae form an interconnected network, giving the sample a welldeveloped schistosity (Fig. 3b, f, g). Hornblende and plagioclase aggregates are elongate and aligned parallel to this fabric (Figs. 3f, g; 4a, b). In places, chlorite can be seen to preferentially occur in the pressure shadows of larger porphyroclasts (Fig. 4b, c).

Sample KMZ30 is a mylonite, consisting of approximately $30 \% 0.1-0.8 \mathrm{~mm}$-sized rounded plagioclase and hornblende clasts in a matrix of very fine-grained $(5-25 \mu \mathrm{m})$ mylonitized plagioclase, chlorite, epidote and quartz (Figs. 3c, 4d). Chlorite and prismatic epidote are the main fabric-defining minerals whereas quartz, plagioclase and hornblende grains are elongated parallel to the fabric (Fig. 4d, e). Chlorite and epidote preferentially occur in the pressure shadows of plagioclase and hornblende clasts (Fig. 4d, e), whereas small cavities are present at grain boundary irregularities (e.g. Fig. 4f).

\subsection{Mineral chemistry}

Mineral compositions were determined using a JEOL JXA8100 electron microprobe housed at the University of Cape Town. Analyses were carried out using a $15 \mathrm{kV}$ acceleration voltage, $20 \mathrm{nA}$ probe current and 2 to $3 \mu \mathrm{m}$ spot size. Counting times were $5 \mathrm{~s}$ for both backgrounds and $10 \mathrm{~s}$ for peaks on all elements. Compositions were quantified using natural mineral standards. Representative mineral compositions for the three samples are presented in Table 1.

All samples show the same trends in mineral compositions, with the amphibole in all samples being hornblende (sensu lato), with appreciable $\mathrm{Al}$ and $\mathrm{Na}$ content (1.5-2 and $0.2-0.25$ cations per formula unit respectively) and $X_{\mathrm{Fe}}$ of
$0.47-0.65$ (Table 1). Large plagioclase grains in all samples exhibit moderate compositional zonation, with anorthite-rich cores grading to more albite-rich rims. Core compositions of $X_{\text {an }}=0.68,0.59$ and 0.47 are observed in the different samples, whereas plagioclase rims are consistently oligoclase with $X_{\text {an }}=0.2-0.25$ (Table 1). The composition of strongly recrystallized plagioclase, such as in the foliated matrix of KMZ29 and KMZ30 is the same as that of the oligoclase rims found on large grains. Chlorite has $X_{\mathrm{Fe}}$ of $0.5-0.66$, mimicking that of hornblende and indicating that the variation in $X_{\mathrm{Fe}}$ between samples is likely controlled by the bulk composition (see also Table 2). Epidote has a pistacite $\left(\mathrm{Fe}^{3+} / \mathrm{Al}+\mathrm{Fe}^{3+}\right)$ content of $0.17-0.3$.

\subsection{Inferred equilibrium mineral assemblages}

All samples contain mineral assemblages and mineral compositions indicative of having equilibrated under amphibolite-facies metamorphic conditions. Some remnants of the preceding granulite-facies history of these rocks is preserved as relict textures in outcrop (Fig. 2a), and possibly in the composition of anorthite-rich plagioclase cores (Table 1), but overall these rocks have been pervasively re-equilibrated (and likely rehydrated) during retrogression. The current equilibrium assemblage in all samples is interpreted to consist of hornblende, plagioclase with $X_{\text {an }} \sim 0.25$, chlorite, epidote, sphene and quartz. The petrography and microstructures indicate that much of this assemblage crystallized synkinematically, as illustrated by the preferential occurrence of chlorite and epidote in the pressure shadows of larger grains (Fig. 4b-e). Similarly, pre-existing hornblende and plagioclase were pervasively recrystallized and their compositions re-equilibrated during KMZ-related shearing. 

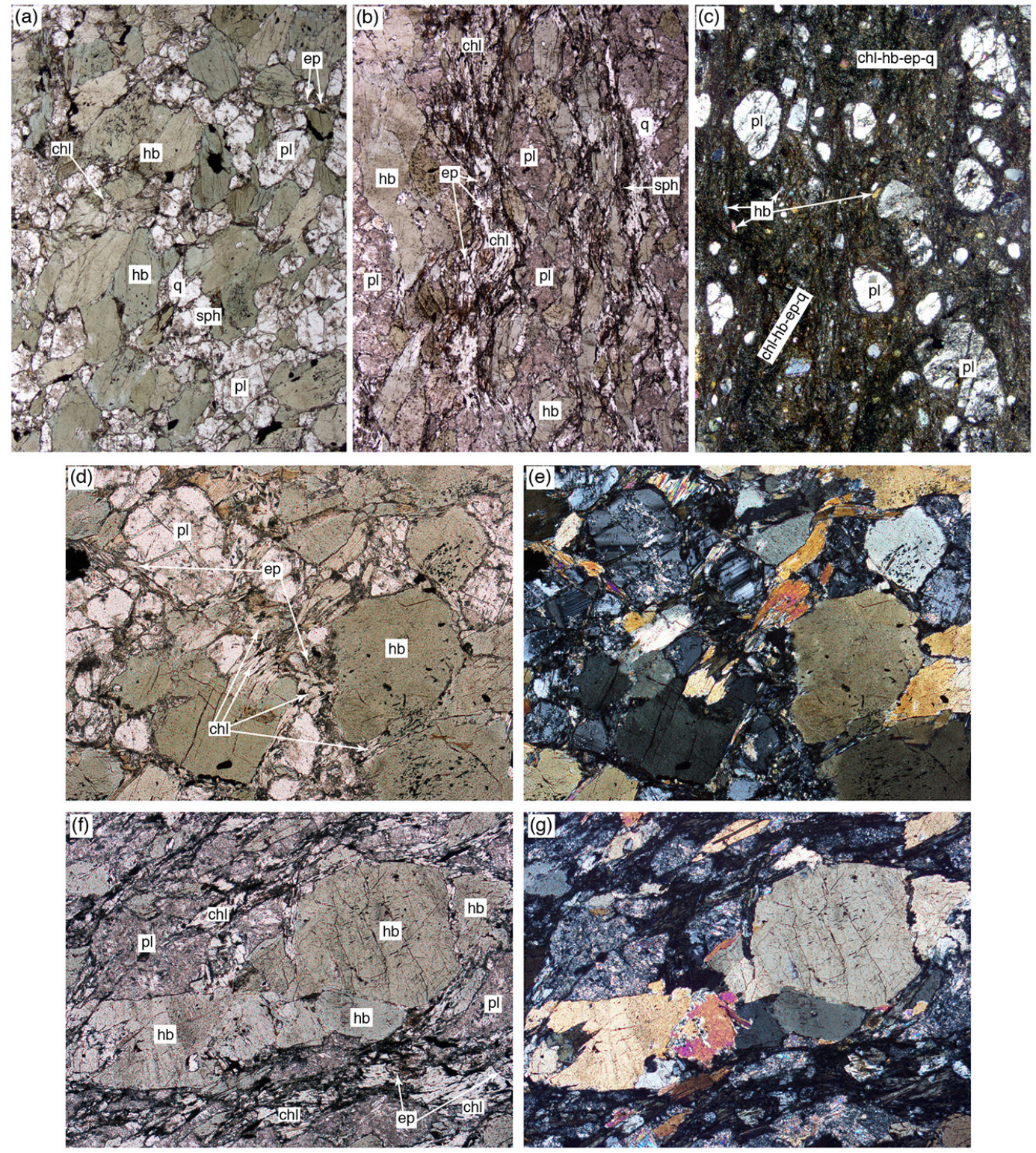

Figure 3. Photomicrographs. (a) Overview of the unsheared texture in KMZ28. Long axis is $4.5 \mathrm{~mm}$, plane-polarized light (ppl). (b) KMZ29 showing elongated hornblende grains alternating with chlorite-epidote foliae. Long axis is $4.5 \mathrm{~mm}$, ppl. (c) KMZ30 consisting of rounded plagioclase and hornblende porphyroclasts in a fine-grained and mylonitized matrix. Long axis is 4.5 mm, cross-polarized light (xpl). Panels (d) and (e) illustrate the largely static breakdown of hornblende to chlorite and epidote with no preferred alignment in KMZ28. Long axis is $2.2 \mathrm{~mm}$ and (d) is in ppl and (e) in xpl. Panels (f) and (g) illustrate subgrain formation and disaggregation of hornblende parallel to the foliation in KMZ29. Long axis is $2.2 \mathrm{~mm}$ and (f) is in ppl and (g) in xpl.

Given the close proximity of the three samples, coupled to the similarities in their mineral assemblages and compositions and the apparent mineral reactions that occurred within each, we infer that they are derived from the same protolith, but experienced different degrees of KMZ-related shearing and perhaps fluid flow, retrogression and metasomatism. The three samples fall on a broad compositional trend, manifested by increases in $\mathrm{Si}$ and $\mathrm{Na}$ coupled to decreases in $\mathrm{Fe}, \mathrm{Mg}$ and $\mathrm{Ca}$, indicating a degree of open-system behaviour dur- ing their KMZ-related metamorphic history (e.g. Fyfe et al., 1978; Spruzeniece and Piazolo, 2015). Sample KMZ28 is largely unaffected by shearing and is also the least altered, whereas KMZ30 is pervasively recrystallized, mylonitised and also the most strongly metasomatized. It is conceivable that these compositional differences were established prior to $\mathrm{KMZ}$ shearing, but it is highly unlikely that they would have led to rheological changes that can explain the strain gradient between the samples. Hence, we interpret the three samples 

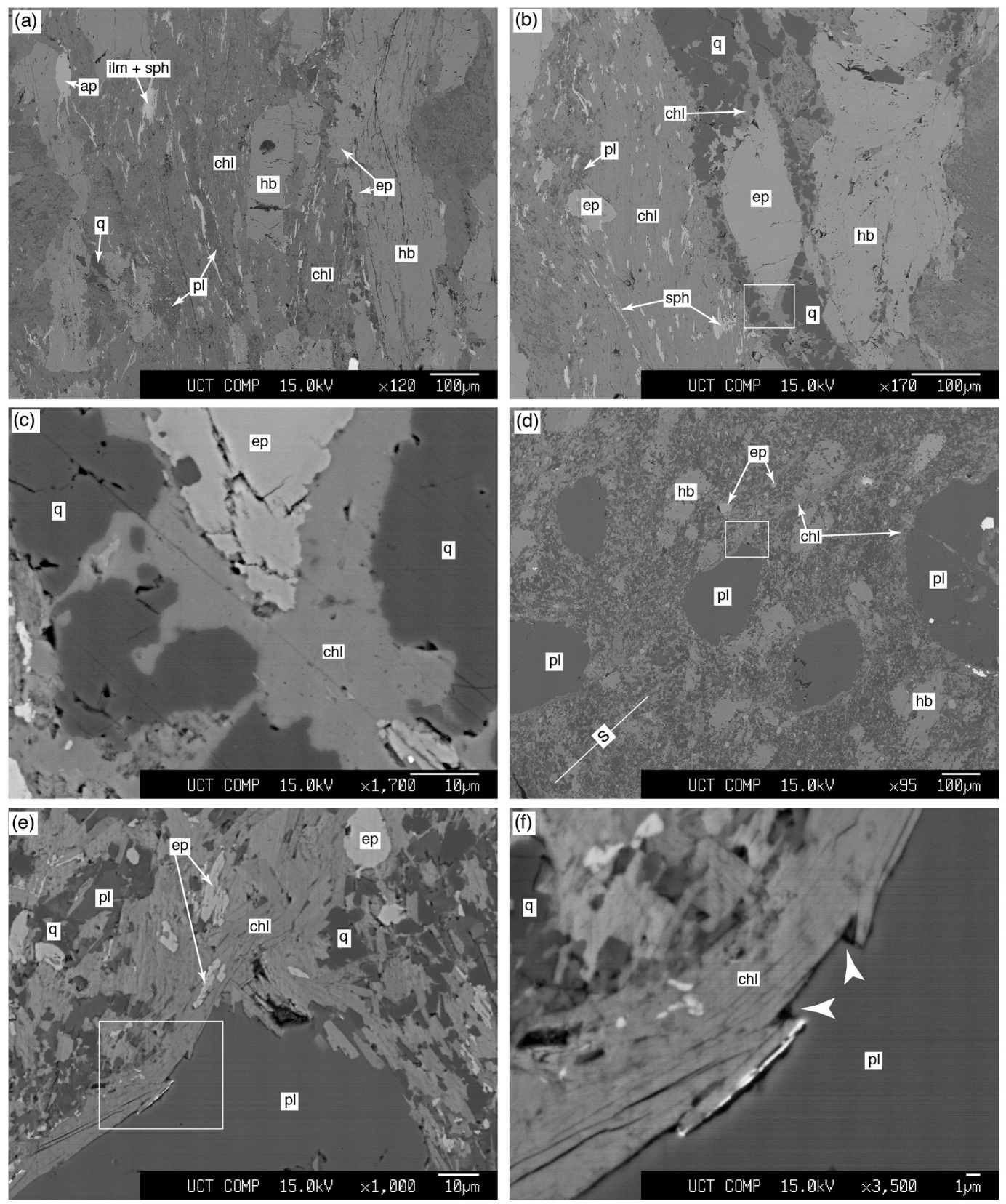

Figure 4. Backscatter electron images. (a) Mineral elongation and alignment in KMZ29. (b) $\sigma$-clast of epidote showing preferential growth of chlorite in its pressure shadows. (c) Detail of the pressure shadow outlined by the box in (b). (d) Rounded plagioclase and hornblende clasts enveloped by a fine-grained and foliated chlorite-epidote-plagioclase-quartz assemblage in KMZ30. Note the preferred growth of chlorite in the pressure shadows of plagioclase and hornblende. (d) Close-up of the area outlined in (d), demonstrating chlorite-epidote growth in the pressure shadow of plagioclase. (e) Close-up of the plagioclase-chlorite grain boundary outlined in (e), showing the presence of pore spaces at grain boundary irregularities (arrowheads).

as variably deformed versions of the same protolith. This, coupled to the synkinematic growth of the assemblage, indicates that the $P-T$ conditions under which the assemblages were equilibrated also brackets the conditions of shearing in the KMZ.

\section{Mineral equilibria modelling}

Mineral equilibria calculations were performed with the THERMOCALC programme by Powell and Holland (1988) using the new and expanded internally consistent thermodynamic dataset by Holland and Powell (2011, dataset 
Table 1. Representative mineral compositions. b.d.: below detection limit; n.d.: not determined.

\begin{tabular}{|c|c|c|c|c|c|c|c|c|c|c|c|c|c|c|c|}
\hline & \multicolumn{5}{|c|}{ KMZ28 } & \multicolumn{5}{|c|}{ KMZ29 } & \multicolumn{5}{|c|}{ KMZ30 } \\
\hline & $\mathrm{hb}$ & pl core & $\mathrm{pl} \mathrm{rim}$ & chl & ep & $\mathrm{hb}$ & pl core & $\mathrm{pl} \mathrm{rim}$ & chl & ep & $\mathrm{hb}$ & $\mathrm{pl}$ core & pl rim & chl & ep \\
\hline $\mathrm{SiO}_{2}$ & 45.83 & 51.15 & 63.37 & 26.39 & 37.64 & 47.58 & 53.45 & 61.67 & 29.17 & 38.9 & 44.41 & 55.96 & 60.11 & 26.29 & 37.53 \\
\hline $\mathrm{TiO}_{2}$ & 1.00 & 0.01 & 0.01 & 0.1 & 0.03 & 0.83 & b.d. & 0.05 & 0.03 & 0.09 & 0.42 & b.d. & 0.01 & 0.05 & b.d. \\
\hline $\mathrm{Al}_{2} \mathrm{O}_{3}$ & 10.61 & 31.97 & 23.49 & 22.33 & 27.04 & 8.51 & 30.86 & 22.85 & 19.1 & 27.76 & 11.5 & 28.67 & 24.8 & 22.37 & 23.52 \\
\hline $\mathrm{Cr}_{2} \mathrm{O}_{3}$ & 0.22 & n.d. & n.d. & 0.08 & b.d. & 0.14 & n.d. & n.d. & 0.24 & b.d. & 0.03 & n.d. & n.d. & b.d. & 0.03 \\
\hline $\mathrm{FeO}$ & 15.5 & 0.05 & 0.28 & 23.36 & 9.45 & 13.18 & 0.09 & 1.26 & 20.11 & 8.1 & 18.52 & 0.17 & 0.14 & 26.58 & 14.21 \\
\hline $\mathrm{MnO}$ & 0.3 & 0.02 & 0.05 & 0.23 & b.d. & 0.34 & 0.05 & 0.04 & 0.27 & 0.19 & 0.58 & 0.03 & b.d. & 0.48 & 0.27 \\
\hline $\mathrm{MgO}$ & 12.36 & b.d. & b.d. & 15.8 & b.d. & 14.76 & b.d. & 0.8 & 19.56 & 0.05 & 10.14 & 0.02 & b.d. & 13.44 & 0.01 \\
\hline $\mathrm{CaO}$ & 11.39 & 13.3 & 3.75 & 0.12 & 23.23 & 11.77 & 11.75 & 3.18 & 0.08 & 22.93 & 11.84 & 9.6 & 4.88 & 0.09 & 22.59 \\
\hline $\mathrm{Na}_{2} \mathrm{O}$ & 0.73 & 3.38 & 8.49 & 0.04 & 0.08 & 0.74 & 4.46 & 7.01 & b.d. & 0.03 & 0.95 & 5.96 & 8.13 & 0.05 & 0.01 \\
\hline $\mathrm{K}_{2} \mathrm{O}$ & 0.36 & 0.06 & 0.1 & 0.46 & 0.14 & 0.24 & 0.07 & 2.36 & 0.03 & 0.02 & 0.61 & 0.09 & 0.93 & 0.34 & 0.01 \\
\hline Total & 98.28 & 99.94 & 99.55 & 88.9 & 97.61 & 98.17 & 100.72 & 99.71 & 88.58 & 98.08 & 98.99 & 100.5 & 99 & 89.69 & 98.18 \\
\hline Oxygens & 23 & 8 & 8 & 14 & 25 & 23 & 8 & 8 & 14 & 25 & 23 & 8 & 8 & 14 & 25 \\
\hline $\mathrm{Si}$ & 6.72 & 2.32 & 2.8 & 2.71 & 6.03 & 6.91 & 2.39 & 2.77 & 2.94 & 6.13 & 6.59 & 2.5 & 2.7 & 2.72 & 6.13 \\
\hline $\mathrm{Ti}$ & 0.11 & 0 & 0 & 0.01 & 0 & 0.09 & - & - & 0 & 0.01 & 0.05 & 0 & 0 & 0 & 0 \\
\hline $\mathrm{Al}$ & 1.83 & 1.71 & 1.22 & 2.71 & 5.11 & 1.46 & 1.63 & 1.21 & 2.27 & 5.16 & 2.01 & 1.51 & 1.31 & 2.73 & 4.53 \\
\hline $\mathrm{Cr}$ & 0.03 & - & - & 0.01 & 0 & 0.02 & 0 & 0 & 0.02 & 0 & 0 & - & - & 0 & 0 \\
\hline $\mathrm{Fe}^{*}$ & 1.9 & 0 & 0.01 & 2.01 & 1.27 & 1.60 & 0 & 0.05 & 1.7 & 1.07 & 2.3 & 0.01 & 0.01 & 2.3 & 1.94 \\
\hline $\mathrm{Mn}$ & 0.04 & 0 & 0 & 0.02 & 0 & 0.04 & 0 & 0 & 0.02 & 0.02 & 0.07 & 0 & 0 & 0.04 & 0.04 \\
\hline $\mathrm{Mg}$ & 2.7 & 0 & 0 & 2.42 & 0 & 3.19 & 0 & 0.05 & 2.94 & 0.01 & 2.24 & 0 & 0 & 2.07 & 0 \\
\hline $\mathrm{Ca}$ & 1.79 & 0.65 & 0.18 & 0.01 & 3.99 & 1.83 & 0.56 & 0.15 & 0.01 & 3.87 & 1.88 & 0.46 & 0.24 & 0.01 & 3.95 \\
\hline $\mathrm{Na}$ & 0.21 & 0.3 & 0.73 & 0.01 & 0.02 & 0.21 & 0.39 & 0.61 & 0 & 0.01 & 0.27 & 0.52 & 0.71 & 0.01 & 0 \\
\hline K & 0.07 & 0 & 0.01 & 0.06 & 0.03 & 0.04 & 0 & 0.14 & 0 & 0 & 0.12 & 0.01 & 0.05 & 0.04 & 0 \\
\hline Total & 15.38 & 4.98 & 4.95 & 9.96 & 16.44 & 15.4 & 4.99 & 4.99 & 9.91 & 16.29 & 15.55 & 5 & 5.02 & 9.94 & 16.61 \\
\hline$X_{\mathrm{an}}$ & & 0.68 & 0.20 & & & & 0.59 & 0.20 & & & & 0.47 & 0.25 & & \\
\hline$X_{\mathrm{Fe}}$ & 0.56 & & & 0.6 & & 0.47 & & & 0.51 & & 0.65 & & & 0.66 & \\
\hline$X_{\mathrm{ps}}$ & & & & & 0.20 & & & & & 0.17 & & & & & 0.30 \\
\hline
\end{tabular}

${ }^{*} \mathrm{All} \mathrm{Fe}$ is recalculated as $\mathrm{Fe}^{2+}$, except for epidote, where all $\mathrm{Fe}$ is assumed to be $\mathrm{Fe}^{3+}$.

Table 2. Bulk compositions (in mole \%) used to construct the pseudosections.

\begin{tabular}{|c|c|c|c|c|c|c|c|c|c|}
\hline & $\mathrm{SiO}_{2}$ & $\mathrm{TiO}_{2}$ & $\mathrm{Al}_{2} \mathrm{O}_{3}$ & $\mathrm{FeO}$ & $\mathrm{MgO}$ & $\mathrm{CaO}$ & $\mathrm{Na}_{2} \mathrm{O}$ & $\mathrm{O}$ & $\mathrm{H}_{2} \mathrm{O}$ \\
\hline Fig. 5a & 51.33 & 0.98 & 10.45 & 9.68 & 13.76 & 10.90 & 2.20 & 0.70 & excess \\
\hline Fig. $5 b$ & 53.98 & 1.02 & 9.32 & 8.94 & 15.73 & 9.17 & 1.11 & 0.72 & excess \\
\hline Fig. $5 c$ & 61.53 & 0.95 & 10.26 & 7.95 & 7.17 & 8.14 & 3.28 & 0.71 & excess \\
\hline Fig. $6 \mathrm{a}\left(M_{\mathrm{H}_{2} \mathrm{O}}=15\right)$ & 43.64 & 0.83 & 8.88 & 8.23 & 11.69 & 9.27 & 1.87 & 0.60 & 15 \\
\hline Fig. $6 \mathrm{a}\left(M_{\mathrm{H}_{2} \mathrm{O}}=3\right)$ & 49.80 & 0.95 & 10.13 & 9.39 & 13.35 & 10.57 & 2.13 & 0.68 & 3 \\
\hline Fig. $6 \mathrm{~b}\left(M_{\mathrm{H}_{2} \mathrm{O}}=16\right)$ & 45.35 & 0.86 & 7.83 & 7.51 & 13.21 & 7.70 & 0.93 & 0.60 & 16 \\
\hline Fig. $6 \mathrm{~b}\left(M_{\mathrm{H}_{2} \mathrm{O}}=2\right)$ & 52.91 & 1.00 & 9.14 & 8.76 & 15.42 & 8.98 & 1.09 & 0.71 & 2 \\
\hline Fig. $6 \mathrm{c}\left(M_{\mathrm{H}_{2} \mathrm{O}}=12\right)$ & 54.15 & 0.84 & 9.03 & 6.99 & 6.31 & 7.16 & 2.89 & 0.62 & 12 \\
\hline Fig. $6 \mathrm{c}\left(M_{\mathrm{H}_{2} \mathrm{O}}=2\right)$ & 60.30 & 0.94 & 10.06 & 7.79 & 7.03 & 7.98 & 3.22 & 0.70 & 2 \\
\hline
\end{tabular}

6.2 created 6 February 2012). Calculations were performed in the $\mathrm{Na}_{2} \mathrm{O}-\mathrm{CaO}-\mathrm{FeO}-\mathrm{MgO}-\mathrm{Al}_{2} \mathrm{O}_{3}-\mathrm{SiO}_{2}-\mathrm{H}_{2} \mathrm{O}-$ $\mathrm{TiO}_{2}-\mathrm{Fe}_{2} \mathrm{O}_{3}$ (NCFMASHTO) model system, disregarding the minor components $\mathrm{MnO}$ (less than $0.2 \mathrm{wt} \%$ ) and $\mathrm{K}_{2} \mathrm{O}$ (less than $1.5 \mathrm{wt} \%$ ). The activity-composition models used are those by White et al. (2014) for chlorite, plagioclase and ilmenite, by Green et al. (2016) for amphibole and by Holland and Powell (2011) for epidote. Albite, sphene, quartz and $\mathrm{H}_{2} \mathrm{O}$ are pure end-member phases. Although a melt model appropriate for mafic rocks is included in Green et al. (2016), melt was not considered in the calculations as the conditions of interest are far below the solidus. However, the calculated equilibria above $\sim 650^{\circ} \mathrm{C}$ are likely to be metastable to melt.
The bulk compositions used in the pseudosection calculations were determined by XRF analysis at the University of Cape Town. Analyses were converted to the NCFMASHTO model system by disregarding $\mathrm{K}_{2} \mathrm{O}, \mathrm{MnO}, \mathrm{Cr}_{2} \mathrm{O}_{3}$ $(<0.03 \mathrm{wt} \%)$ and $\mathrm{P}_{2} \mathrm{O}_{5}(<0.2 \mathrm{wt} \%)$ and assuming approximately $15 \%$ of total $\mathrm{Fe}$ to be present as $\mathrm{Fe}^{3+}$, in line with typical values for metamafic rocks (cf. the compilation of Rebay et al., 2010). During initial modelling, the samples were assumed to be fully hydrated, such that water $\left(\mathrm{H}_{2} \mathrm{O}\right)$ was taken to be present in excess. The possibility of variable rehydration during retrogression is explicitly considered later. The bulk compositions used to construct the pseudosections are presented in Table 2. 

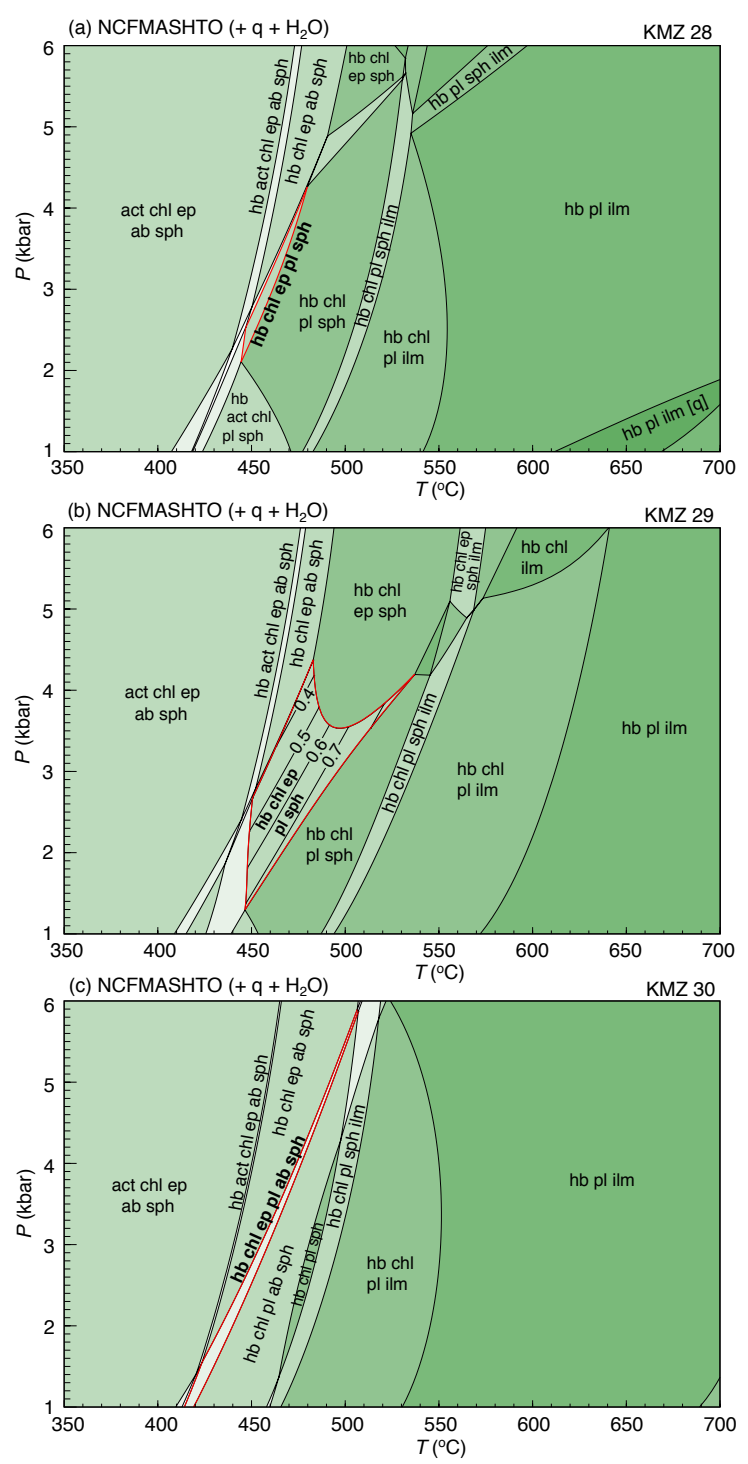

Figure 5. $P-T$ pseudosections calculated for mafic schists from the KMZ. The inferred equilibrium mineral assemblages are outlined by red boxes and indicated in bold type. Contours in (b) are for $X_{\mathrm{an}}$ in plagioclase.

\section{1 $\quad P-T$ pseudosections}

Fluid-saturated $P-T$ pseudosections for samples KMZ28, KMZ29 and KMZ30 are presented in Fig. 5. The phase relations in all three samples have a similar topology and consist of the typical greenschist-facies assemblage actinolitechlorite-epidote-albite-sphene-quartz at $T$ below $450{ }^{\circ} \mathrm{C}$ and contain the typical amphibolite-facies assemblage of hornblende-plagioclase-ilmenite-quartz at $T$ above 550$600^{\circ} \mathrm{C}$ (Fig. 5). In the $T$ range between 450 and $550-600^{\circ} \mathrm{C}$, these rocks undergo a series of phase changes, notably (1) the introduction of hornblende at the expense of actinolite, (2) the introduction of plagioclase and the demise of al- bite and epidote, (3) the replacement of sphene by ilmenite and finally (4) the demise of chlorite (Fig. 5). Within this $T$ zone, the inferred equilibrium assemblage of hornblendeplagioclase-chlorite-epidote-sphene occurs in a narrow, $T$ sensitive field at around $450^{\circ} \mathrm{C}$ and between 2 and $4 \mathrm{kbar}$ in KMZ28 and KMZ29 (Fig. 5a, b), but spans the entire $P$ range of interest in KMZ30 (Fig. 5c). This field is bound by the removal of plagioclase to lower $T$ and the loss of epidote to higher $T$. Contours of $X_{\text {an }}$ calculated for KMZ29 indicate that the composition of plagioclase varies substantially, from $X_{\text {an }}=0.32$ to $X_{\text {an }}=0.82$, at the stability conditions of the inferred equilibrium assemblage (Fig. 5b).

\section{2 $T-M_{\mathrm{H}_{2} \mathrm{O}}$ pseudosections}

Calculated $T-M_{\mathrm{H}_{2} \mathrm{O}}$ pseudosections allow the degree of fluid saturation in these rocks to be quantitatively evaluated and are presented for the three samples in Fig. 6. The diagrams are calculated at constant $P$ of $4 \mathrm{kbar}$ in order to bracket the peak-to-retrograde evolution, with $\mathrm{H}_{2} \mathrm{O}$ content chosen to vary such that the samples are fluid saturated and undersaturated over the $T$ range of interest. THERMOCALC outputs $\mathrm{H}_{2} \mathrm{O}$ content as a mol fraction, but this approximates volume percent when normalized to 1 oxide sum total.

The pseudosections all show a similar topology and exhibit the same features, notably that all samples require high $\mathrm{H}_{2} \mathrm{O}$ content to be fluid saturated at low- $T$ greenschistfacies conditions $\left(M_{\mathrm{H}_{2} \mathrm{O}}=11-15 \mathrm{~mol} \%\right)$, but that only about a third of this fluid is required for fluid saturation under amphibolite- to granulite-facies conditions $\left(M_{\mathrm{H}_{2} \mathrm{O}}=\right.$ 3-5 mol \%; Fig. 6). Consequently, all samples undergo large changes to their fluid content in the range between 450 and $550-600^{\circ} \mathrm{C}$, with $\sim 7-10$ vol. $\% \mathrm{H}_{2} \mathrm{O}$ being produced if the rocks were heating up; conversely the same amount of rehydration from an external source is required to maintain fluid saturation during cooling (Fig. 6).

The maximum amount of $\mathrm{H}_{2} \mathrm{O}$ that these rocks could have retained from peak metamorphic conditions $\left(T>750^{\circ} \mathrm{C}\right.$; Diener et al., 2013) is $3-5 \mathrm{~mol} \%$, depending on the sample (Fig. 6). However, the mineral assemblages observed in the three samples all straddle the $\mathrm{H}_{2} \mathrm{O}$ saturation line at $\sim 480^{\circ} \mathrm{C}$, indicating that they can occur at fluid-saturated or slightly fluid-undersaturated conditions, but require a higher $\mathrm{H}_{2} \mathrm{O}$ content of at least $5.5-11.5 \mathrm{~mol} \%$, depending on the sample (Fig. 6, red boxes). The observed assemblages are bound by the loss of epidote and plagioclase to lower $\mathrm{H}_{2} \mathrm{O}$ content. As $\mathrm{H}_{2} \mathrm{O}$ content is decreased further at $480^{\circ} \mathrm{C}$, ilmenite is introduced, prior to the loss of sphene and chlorite, and finally the introduction of orthopyroxene and garnet at the very low $\mathrm{H}_{2} \mathrm{O}$ content that characterized peak metamorphic conditions $\left(M_{\mathrm{H}_{2} \mathrm{O}}<3-5 \mathrm{~mol} \%\right.$; Fig. 6). 


\section{Discussion}

(a) NCFMASHTO $(+q)$

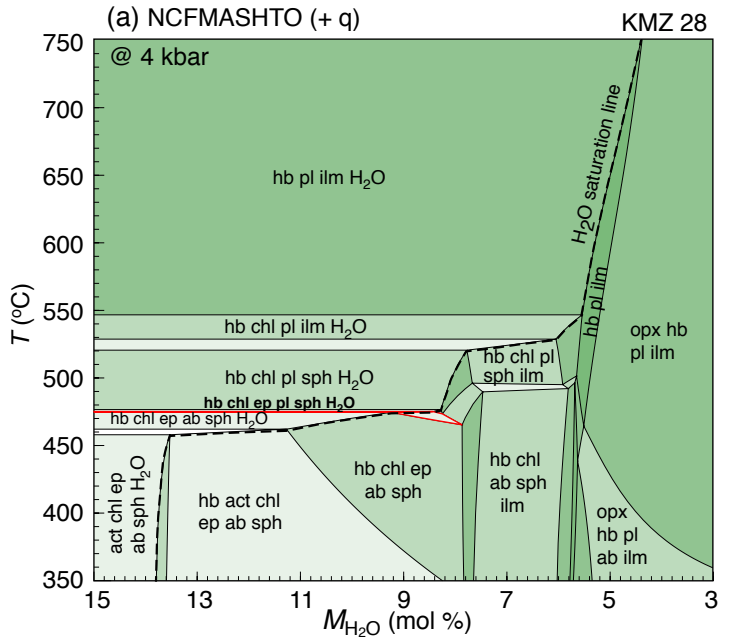

(b) NCFMASHTO $(+q)$

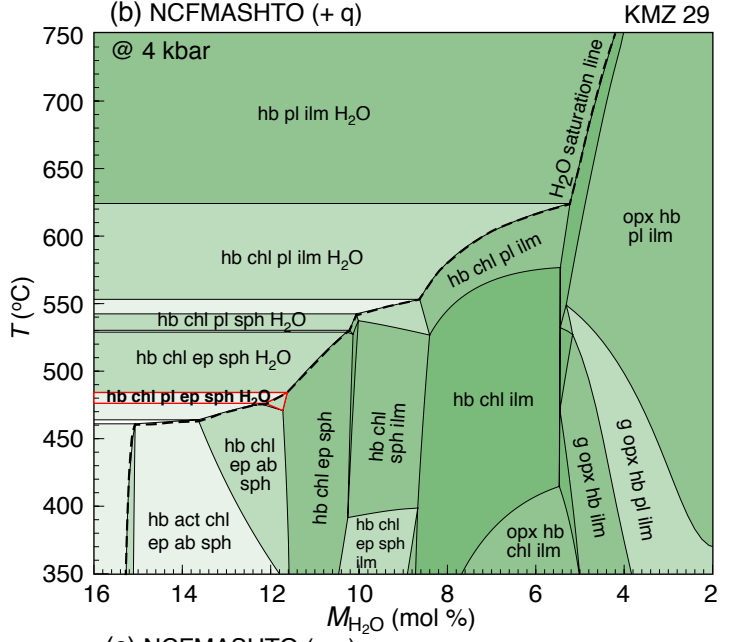

(c) NCFMASHTO (+ q)

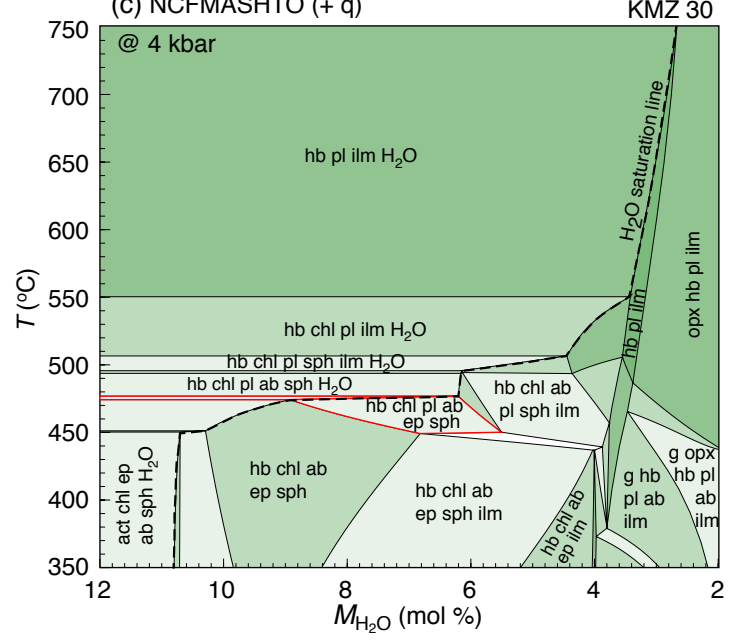

Figure 6. $T-M_{\mathrm{H}_{2} \mathrm{O}}$ pseudosections for mafic schists from the KMZ. $\mathrm{H}_{2} \mathrm{O}$-saturated assemblages are separated from $\mathrm{H}_{2} \mathrm{O}$ undersaturated assemblages by the thick dashed line. The observed assemblages are outlined by red boxes.

\section{1 $\quad P-T$ conditions of shearing}

The three samples described above were affected by KMZrelated retrograde deformation to different degrees and can, therefore, be used to effectively constrain the $P-T$ conditions under which quasi-plastic shearing in the KMZ occurred. The stability of the observed assemblages are summarized in Fig. 7, and the overlap between the samples constrains the most likely $P-T$ conditions experienced by these rocks at $2.7-4.2 \mathrm{kbar}$ and $450-480^{\circ} \mathrm{C}$. Whereas $T$ is tightly constrained, the $P$ estimate is less precise and straddles the kyanite-andalusite phase boundary. However, no aluminosilicates are present in the KMZ, nor have they been reported for other parts of the MRPSZ; consequently the presence of kyanite or andalusite cannot be used to refine the $P$ estimate further.

The estimates indicate that the bulk of shearing in the $\mathrm{KMZ}$ occurred at $450-480^{\circ} \mathrm{C}$, at a depth of $10-16 \mathrm{~km}$, assuming overlying granitic crust. These conditions are significantly warmer than the brittle-viscous transition in quartz (Hirth et al., 2001), and the unstable-stable frictional transition in granitic rocks (Blanpied et al., 1995), and roughly coincides with the onset of crystal-plastic deformation of feldspar at geological strain rates (Pryer, 1993; Rybacki and Dresen, 2000). These inferred conditions are consistent with frictional-viscous flow (sensu Handy et al., 1999) in felsic KMZ mylonites, where bulk deformation occurred by viscous flow of interconnected quartz-phyllosilicate networks surrounding locally brittle feldspar clasts (Rennie et al., 2013). The lack of a greenschist-facies overprint on the mineralogy of the samples, as well as lack of a pervasive brittle overprint to the deformation, strongly indicates that shearing in the KMZ ceased at these $T$ and that deformation along the shear zone did not lead to progressive exhumation and attendant cooling as the KMZ developed (cf. Till et al., 2007).

Whereas the KMZ lacks an obvious lower- $T$ history, it is localized in lithologies that experienced earlier granulitefacies metamorphism, such that it could potentially have an inherited higher- $T$ history. The available age data indicate that the MRPSZ was active at ca. 1005-960 Ma (Macey et al., 2014; Melcher et al., 2015), such that the KMZ could post-date peak metamorphism (1065-1045 Ma; Diener et al., 2013) by as little as $40 \mathrm{Ma}$. However, apart from local textural indications preserved in low-strain areas (e.g. Fig. 2a), the mineralogical features have been pervasively overprinted at the $P-T$ conditions constrained above. One mineralogical aspect that could potentially be inherited from the earlier high- $T$ history is the anorthite-rich composition preserved in plagioclase cores. However, calculated isopleths of anorthite content in plagioclase (only shown for KMZ29 in Fig. 5b) indicate that the plagioclase composition varies widely at or near the $P-T$ constrained for the KMZ. This does not preclude the plagioclase cores being inherited from earlier 


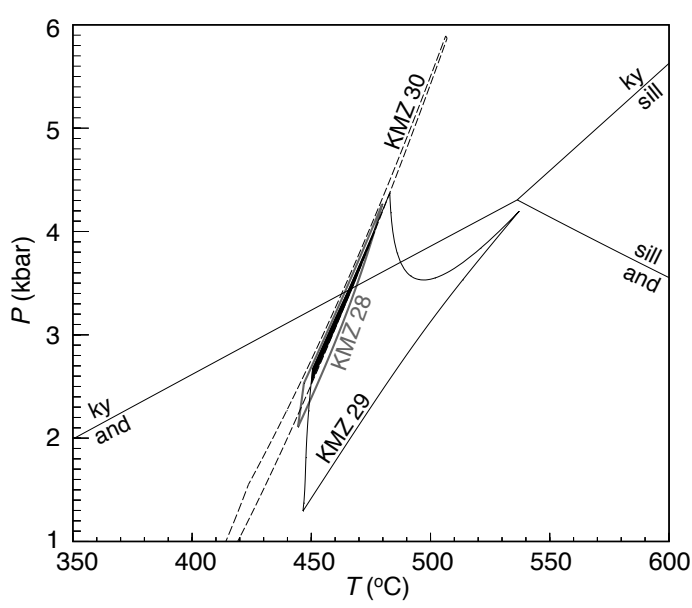

Figure 7. Summary of estimated $P-T$ conditions for the KMZ, constrained from the $P-T$ overlap of the equilibrium assemblages that occur in the various mafic schists.

higher- $T$ conditions, but shows that the core compositions are not far from equilibrium, with the remaining assemblage at $450-480^{\circ} \mathrm{C}$. Consequently, it appears plausible that shearing along the KMZ occurred at near-constant $T$ conditions of $\sim 450^{\circ} \mathrm{C}$ at a depth within the range of 10 to $16 \mathrm{~km}$ and that the KMZ did not undergo progressive exhumation and cooling during its development. The KMZ is, therefore, related to a discrete tectonic event and does not form a continuum of earlier granulite-facies metamorphism, which is supported by its large-scale structural discordance with the granulite-facies structures and fabrics (Jackson, 1976; Toogood, 1976; Moen and Toogood, 2007; Miller, 2008; Rennie et al., 2013). It also follows that the KMZ likely acted as a transcurrent shear zone, with little-to-no associated transpression or transtension.

The tectonic and $P-T$ history of the KMZ is similar to that of modern examples of major continental strike-slip shear zones that are localized in isostatic/non-orogenic crust and do not involve large amounts of crustal thickening or thinning. Such modern examples include the San Andreas fault away from the Mendocino Triple Junction and transpressional/transtensional bends (Guzofski and Furlong, 2002; Spotila et al., 2007) and the North Anatolian fault east of the Aegean transtensional zone (Hubert-Ferrari et al., 2002). The thermal profile of these shear zones follow the continental geotherm that is stable at the time, which in the case of the $\mathrm{KMZ}$ is estimated at $30-45^{\circ} \mathrm{C} \mathrm{km}^{-1}$. The uncertainty in this estimate is caused by uncertainty in the depth of the KMZ, but the entire range is significantly warmer than for stable continental lithosphere $\left(\sim 20^{\circ} \mathrm{C} \mathrm{km}^{-1}\right.$; e.g. Cooper et al., 2002, and references therein). However, given that the Aus granulite terrain experienced granulite-facies metamorphism associated with lithospheric thinning only $40 \mathrm{Ma}$ earlier, it is to be expected that the terrain was characterized by higherthan-average heat flow at the time of shear zone formation (e.g. Morrissey et al., 2014; Bial et al., 2015). In fact, the estimated geotherm is comparable with those derived from crust underlain by young and thin lithosphere, such as the northern San Andreas fault (Fagereng and Diener, 2011).

\subsection{Fluid regime, fluid source and infiltration mechanisms}

The rocks in which the KMZ localized were dehydrated and experienced partial melting and melt loss during preceding metamorphism (Diener et al., 2013). In the absence of rehydration, the rocks would have retained their (low) fluid content and granulite mineralogy from peak metamorphic conditions and experienced shearing and reworking under fluid-absent conditions (Guiraud et al., 2001; White and Powell, 2002; Tenczer et al., 2006; Diener et al., 2008). If this were the case, the samples would have consisted of orthopyroxene-bearing assemblages and would have grown garnet at the $P-T$ conditions of shearing $\left(450-480^{\circ} \mathrm{C}\right.$ and $M_{\mathrm{H}_{2} \mathrm{O}}<3-5 \mathrm{~mol} \%$; Fig. 6; cf. Dziggel et al., 2012). For the rocks to have replaced their high- $T$ assemblages with the minerals observed in the samples described here, they must have experienced an addition of $\mathrm{H}_{2} \mathrm{O}$ (Fig. 6). The observed assemblages in all three samples straddle the $\mathrm{H}_{2} \mathrm{O}$ saturation line, indicating that they can occur at fluid-saturated or slightly fluid-undersaturated conditions. However, given that the absolute fluid content required by each assemblage differs widely between the samples, it appears unlikely that the samples were all rehydrated to be just fluid undersaturated, and it is more plausible to conclude that they were fully rehydrated and fluid saturated during shearing along the KMZ.

The mineral assemblages described here, therefore, demand at least some syntectonic retrograde rehydration during strike-slip displacement in a dominantly viscous shear zone. Calculations show that rehydration requires the addition of 4-8 vol. $\% \mathrm{H}_{2} \mathrm{O}$ (Fig. 6), such that a fluid/rock ratio of at least $0.05-0.1$ is necessary to ensure rehydration and fluid saturation of the KMZ if fluid uptake is assumed to be efficient. Other than the presence of hydrous mineral phases, formed syntectonically from a relatively dry protolith, there are, however, few observed signs of extensive fluid flow. Whereas the change in bulk composition between the samples indicates a degree of metasomatic open-system behaviour, the shear zone is largely barren of hydrothermal precipitates and quartz veins, other than a few local (up to tens of metres along-strike) examples of foliation-parallel veins with mylonitic lineation. A few very late, subvertical, tens of centimetres thick, north-striking veins cross-cut the KMZ mylonitic fabrics. Thus, we envisage that fluid flow during shearing was sufficient to completely rehydrate the mineral assemblages and allow the presence of a free fluid phase, but that it was not extensive enough to allow widespread hydrothermal precipitation. Similarly, we envisage that fluid flow occurred either along grain boundaries or through small-length-scale fracture systems (which were 
subsequently healed, thus not preserved) rather than through long-lived, channelized conduits.

Kilometre-scale, open-system diffusion of water through crustal shear zones is not a unique phenomenon and was proposed by Beach (1980) for major retrogression in ductile shear zones cross-cutting the Archaean Lewisian basement complex of northern Scotland, in similar settings and metamorphic conditions to the current study. Similarly, significant retrograde fluid influx has been inferred for shear zones at Broken Hill, Australia (Etheridge and Cooper, 1981), the French Pyrenees (McCaig et al., 1990) and the Yellowknife gold district, Canada (Kerrich et al., 1977); in the latter location, fluid flux is associated with hydrothermal vein mineralization as well as retrograde reactions. Based on these and other examples, it has been estimated that typical fluid/rock ratios in retrogressed shear zones can exceed $10^{2}$ (Etheridge et al., 1983) and can locally be much greater (Kerrich et al., 1977; McCaig et al., 1990). This is 3 orders of magnitude higher than the minimum fluid/rock ratio required for the $\mathrm{KMZ}$, which again indicates that, although the KMZ was fluid saturated, it was likely not inundated with fluid to the same extent as many other examples of retrograde shear zones.

Achieving retrograde rehydration requires a significant source of fluids. Such a source is not obvious in a depleted, dry, granulite terrain such as the Aus granulites hosting the KMZ. Etheridge et al. (1983) suggest hydrothermal circulation of prograde fluids, driven by a mantle heat source, as typical of regional metamorphism at depths $>10 \mathrm{~km}$, but no prograde fluid source is available during strike-slip deformation of the KMZ. For retrograde metamorphism and rehydration, Etheridge et al. (1983) imply that tectonic juxtaposition of hot rocks and cool, fluid-saturated mineral assemblages can drive dehydration and provide local fluids. Again, this is not feasible in the $\mathrm{KMZ}$, as the strike-slip motion provides neither a heat source nor a fluid source. In a review of fluids in deep fault zones, Kerrich et al. (1984) proposes that retrograde deformation with high fluid/rock ratios requires an external, typically meteoric, fluid source. Such a meteoric fluid source is evident in current deformation along and around the Alpine fault, New Zealand, where retrograde deformation is associated with transpression and topographically driven deep circulation of meteoric waters in the southern Alps (Koons and Craw, 1991; Menzies et al., 2014). However, this model requires a component on crustal shortening and associated mountain building to create the hydraulic head to drive surface fluids down to below the brittle-viscous transition.

McCaig et al. (1990) suggest that high fluid/rock ratios of up to $10^{3}$ can be achieved through episodic seismic pumping of a meteoric fluid and local, transiently enhanced permeability of $10^{-17}$ to $10^{-15} \mathrm{~m}^{2}$. In their model, the meteoric fluids move down a gently dipping décollement and then up through steeply dipping shear zones. No such gently dipping décollement is know to exist below the KMZ, but one could potentially envisage seismically driven meteoric fluid flow down to the KMZ, from the brittle crust above (McCaig, 1988), but this mechanism still requires high permeability into the ductile lower crust. Such enhanced permeability may come about through aseismic processes, considering that retrograde reactions lead to volume change. The study by O'Hara (1988) implies volume loss during retrograde breakdown of feldspar coupled to fluid influx as the origin of phyllonitisation, reaction weakening and mylonitisation in an overthrust setting in the Appalachians. Jamtveit et al. (2008), on the other hand, suggest extensive microfracturing associated with retrograde hydration and increase in solid volume as another mechanism to get fluids into otherwise low-permeability, high-grade crystalline rocks. Even without associated retrograde reaction, creep has been shown to enhance permeability through generation of grain boundary microcracks (McCaig and Knipe, 1990; Peach and Spiers, 1996), grain boundary dissolution porosity (Billia et al., 2013) and through a dynamic process of creep cavitation (Fusseis et al., 2009; Menegon et al., 2015). Porosity seen along grain boundaries (Fig. 4f) indicates the possibility of grain boundary permeability, allowing fluid flow and enhancing grain boundary sliding (Mancktelow et al., 1998; Menegon et al., 2006; Fusseis et al., 2009). Thus, the presence of a retrograde shear zone, once actively deforming, is a source of locally elevated permeability - either from solid volume increase and associated microfracturing, or solid volume decrease and associated grain boundary dilatancy. This permeability may be transiently enhanced by earthquake rupture and associated fault zone damage in the brittle crust overlying the shear zone and potentially through downward propagation of such rupture fronts into the ductile regime (McCaig, 1988).

The above examples all include an element of dip-slip displacement. In another example of fluids in a subvertical strike-slip shear zone, the deep San Andreas fault is suspected to be fluid rich, based on high $V p / V s$ in the lower crust (Ozacar and Zandt, 2009). A likely source for this fluid is a serpentinized mantle wedge, where serpentinization dates to past subduction and the absence of a cool, insulating slab now leads to heating and dehydration (Kirby et al., 2002; Fulton and Saffer, 2009). This San Andreas fault case is, however, somewhat special in requiring a transition from subduction to strike-slip tectonics, and we do not see evidence for the presence of a similar serpentinized mantle wedge as a source of fluids for KMZ rehydration, neither does the tectonic history of the Namaqua-Natal Belt call for an initial subduction origin for the MRPSZ. Thus, while we do not preclude other alternatives, our best hypothesis is that the external fluid source for $\mathrm{KMZ}$ rehydration was meteoric, and fluid flow was allowed by local dilation and/or increased fracture permeability within the shear zone, thus accounting for retrograde metamorphic reactions within the mylonites and absence of such reactions outside the KMZ. 


\subsection{Initiation and feedback mechanisms in a retrograde shear zone}

In the previous section, we argue for an external fluid source to allow retrograde rehydration reactions to occur in the KMZ. Although we suggest a meteoric origin as most likely, another origin for the external fluid does not change the arguments and conclusions that will next be made regarding the effects of fluid infiltration and retrograde reactions on fault zone rheology. Retrograde minerals within the mylonites define syntectonic fabric elements (Fig. 4b-e), thus indicate syntectonic retrogressive reaction and hydration. The implication that hydration, metamorphism and deformation occurred concurrently and were mutually enhancing raises a chicken-and-egg question regarding the onset of retrograde metamorphism and shear zone deformation. However, if the interpretation that the fluids source was external is correct, and we know retrograde mineral assemblages are localized in the KMZ, it is implicit that the shear zone must have been a region of enhanced permeability before retrograde reactions could initiate. Moreover, if the fluid source was near-surface and fluids came into the KMZ through the overlying brittle crust, it is required that (1) a fault system in the brittle crust was present and linked to the KMZ and (2) the KMZ was already there to provide a low-permeability zone for such fluids to localize into.

Beach (1980) concluded that in early stages of ductile deformation, fluids preferentially flow into the deforming zone, and the consequent initiation of retrograde metamorphic reactions initiate reaction softening and further strain localization. Thus, as soon as a shear zone is active at retrograde conditions and connected to an external fluid reservoir, we envisage a positive feedback loop where reaction softening and ongoing metamorphic reactions lead to progressive strain accumulation, weakening and permeability enhancement. The feedback mechanisms involved include (1) grainsize reduction through growth of new minerals, enhancing diffusion rates (Rutter, 1976; Beach, 1980); (2) low cohesion along new grain boundaries, enhancing grain boundary sliding (White and Knipe, 1978); (3) second phase pinning that restricts grain size, maintaining a fine grain size that enhances grain-size sensitive creep as the main deformation mechanism (Fliervoet et al., 1997; de Ronde et al., 2005; Herwegh et al., 2011; Kilian et al., 2011) and (4) replacement of strong mineral phases with weaker phyllosilicates (Wintsch et al., 1995; Imber et al., 1997). We do not exclude a possibility that this early stage of ductile deformation initiated on a pre-existing brittle fracture (Mancktelow and Pennacchioni, 2005), or in rock locally more hydrous (Getsinger et al., 2013); however, we do not record evidence of existing fractures, and local fluid infiltration would involve late granulite-facies magmatic fluids related to granites not observed in direct contact with the shear zone rocks we discuss here. Therefore it seems equally or more likely that a new shear zone within a dry granulite terrane should initiate ei- ther along an existing well-oriented fabric (Worley and Wilson, 1996; Montesi, 2013; Rennie et al., 2013), or around a stress riser such as a pretectonic granitic intrusion (Goodwin and Tikoff, 2002; Rennie et al., 2013). Spruzeniece and Piazolo (2015) describe a similar example of deformation localization into a metre-scale fine-grained ultramylonite with increased metasomatic Si content and suggest that fluids were required to initiate metasomatism and localized deformation, but were introduced through brittle precursor fracture systems. We do not see such definite evidence for a brittle precursor, but also prefer a conclusion where deformation localization allowed localized fluid flow, either through a brittle precursor or activation of existing fabrics, locally or further afield. Note that shear zone propagation may be more pertinent here than nucleation, given that the KMZ may have initiated outside the study area in a different rock assemblage. Independently of the exact initiation mechanism, we stress that as soon as a shear zone has initiated in strong, dry rocks at retrograde conditions, the interplay between reaction and deformation will cause further weakening, enhancing strain localization, thus significant local weakening of the lower crust will occur.

It has long been envisaged that as a viscous shear zone accumulates strain, grain-size reduction caused by metamorphic growth of new grains and recrystallization through dislocation creep competes with grain growth through diffusion (White, 1976). Thus, retrograde shear zones are commonly predicted to initiate with fine grain sizes and dominantly deform by diffusion creep, but as grains grow and the mineral assemblage equilibrates at the retrograde $P-T$ conditions, grain size should increase and the deformation mechanism may change to dominantly dislocation creep (White, 1976; Beach, 1980). We note, however, that in our samples (Fig. 3), as in microstructures reported by Rennie et al. (2013) from the KMZ, the highest strain rocks are characterized by a very fine-grained, intensely foliated, retrograde mineral assemblage. This fine grain size may be a result of second phase pinning preventing grain growth, thus enhancing grain-size sensitive creep (Fliervoet et al., 1997; de Ronde et al., 2005; Kilian et al., 2011). The general lack of veins may further imply that fluid pressures were not sufficient to allow hydrofracturing and mineral precipitation; however, precipitation may also have been hindered by low solubility and low dissolved mineral content in cool fluids derived from above the shear zone. It is, however, implied by a meteoric fluid source that connectivity with the surface existed, at least temporarily, under which fluid pressure cannot have been greater than hydrostatic. Thus, overall, we do not see high fluid pressures as a necessary nor likely weakening mechanism in retrograde shear zones that are connected to an external fluid source, particularly if this fluid source is related to a surfaceconnected fracture system. 


\subsection{Implications for strength and deformation mechanisms in active retrograde viscous shear zones}

We have inferred from the $P-T$ path derived from lowand high-strain rocks that the KMZ represents a retrograde shear zone deformed at relatively constant temperature, just warmer than the brittle-viscous transition in granitic rocks. Further, the mylonites record simultaneous retrograde grain growth and strike-slip deformation, explained by localized fluid flow through an active shear zone. Because the shear zone was hosted in dry, melt-depleted and strong granulitefacies rocks (e.g. Jackson, 2002; Afonso and Ranalli, 2004; Fitz Gerald et al., 2006) that retain migmatitic and gneissic fabrics, the bulk of the fluid must have been derived externally. The shear zone does not preserve pervasive hydrofractures, but does preserve very fine-grained mineral assemblages likely associated with diffusive mass transfer, as evidenced by a strain localization in a fine-grained polyphase aggregate with preferential growth of reaction products in dilatant sites. In addition, synkinematic fine-grained plagioclase have a different composition than prekinematic plagioclase cores (Table 1), a possible sign of nucleation from solution during deformation, after which fine-grained precipitates would have deformed by grain-size sensitive creep (Fukuda and Okudaira, 2013). Coupled to the inference of an external fluid source, the scarcity of veins and prevalence of a fine-grained assemblage lead to the inference that the shear zone was active at low fluid pressure conditions, and weakening relative to surrounding wall rocks was caused by reaction weakening, involving grain-size reduction and growth of relatively weak minerals (e.g. chlorite). These inferences imply that as soon as a retrograde shear zone has formed, and as long as it retains connection to a reservoir of fluids, such a shear zone is a long-lived, strain-weakening feature that controls the strength of the lower crust over its along-strike extent.

The San Andreas fault is inferred to be weak and wet (e.g. Ozacar and Zandt, 2009), commonly explained by high fluid pressures (Rice, 1992). The Alpine fault, New Zealand, has on the other hand been interpreted as frictionally strong (Boulton et al., 2014) and potentially weakened at depths by fluid presence (Wannamaker et al., 2002). Both of these faults are currently active under retrograde metamorphic conditions and exhibit tectonic tremor, a persistent low-frequency seismic signal characterized by lack of impulsive body wave arrivals, emanating from below the brittle-viscous transition (Shelly, 2010; Shelly and Hardebeck, 2010; Wech et al., 2012). These tremor signals have, in both places, been interpreted as fluid-enabled slip on the deep extension of the plate boundary faults, below the base of the seismogenic zone (Shelly and Hardebeck, 2010; Wech et al., 2012). The KMZ is exhumed from the same thermal and metamorphic regime where the San Andreas and Alpine fault tremor occurs. The KMZ also deformed un- der fluid-present conditions and was significantly weak compared to surrounding rock. However, our observations and inferences along the KMZ require fluid presence, but do not require elevated fluid pressure to explain this weakening. As suggested by Fagereng and Diener (2011) for the San Andreas fault, we also suggest that deformation localization below the brittle-viscous transition at retrograde conditions may be a function of reaction weakening and metamorphic rehydration. At these conditions, localized slip may occur along weak planes characterized by aligned phyllosilicates (Wintsch et al., 1995; Imber et al., 1997), possibly associated with transient aseismic creep accommodated in finegrained mylonites deforming by diffusion creep. If this interpretation is correct, high fluid pressures are not required for tremor and slow slip in the viscous regime in retrograde shear zones. Instead, weakness of fluid-saturated, retrograde faults and shear zones may be explained by reaction weakening under hydrostatic fluid pressure conditions.

\section{Conclusions}

The KMZ was localized in dry, high-grade mid-crustal gneisses. Once shearing was active, it allowed externally derived fluids to infiltrate the $\mathrm{KMZ}$ and activate a number of positive feedback processes that allowed weakening and continued strain localization. The observed mineral assemblages lead us to conclude that the KMZ was fluid bearing during deformation, but the general absence of hydrofractures and hydrothermal precipitates indicate that fluid pressures and the fluid/rock ratio remained low. In this regard the KMZ differs from most other exhumed and active continental retrograde shear zones for which high fluid/rock ratios have been suggested (Kerrich et al., 1977; Etheridge et al., 1983; McCaig et al., 1990) or for which high fluid pressures are inferred (Rice, 1992; Ozacar and Zandt, 2009). It consequently appears that retrograde shearing can be sustained under a variety of fluid regimes, from dry and entirely fluid absent (Tenczer et al., 2006), through low-volume fluid presence such as described here, to examples where shear zones are inundated and dominated by fluid. There is also a range in cases from where high fluid pressures are sustained by a combination of high fluid volumes and low permeability, to shear zones where either low fluid volumes or high permeability prevent the build-up of high fluid pressures. Therefore we conclude that the dominant contribution of fluids to sustaining localized deformation under retrograde conditions can be through reaction weakening, by producing weaker mineral phases and facilitating grain-size reduction. We also conclude that weak lower crustal, fluid-bearing shear zones do not need to imply high fluid pressures, but can also be significantly weaker than surrounding wall rocks from reaction weakening at hydrostatic fluid pressure conditions. 
Acknowledgements. Luca Menegon and Florian Fusseis are thanked for helpful reviews that improved and clarified the manuscript. This work is based on research supported by research development grants from the University of Cape Town. We thank Koos and Anna Bosman for access to their land and their hospitality during field work.

Edited by: F. Rossetti

Reviewed by: L. Menegon and F. Fusseis

\section{References}

Afonso, J. C. and Ranalli, G.: Crustal and mantle strengths in the continental lithosphere: Is the jelly sandwich model obsolete?, Tectonophysics, 394, 221-232, 2004.

Andersen, T. B., Mair, K., Austrheim, H., Podladchikov, Y. Y., and Vrijmoed, J. C.: Stress release in exhumed intermediate and deep earthquakes determined from ultramafic pseudotachylyte, Geology, 36, 995-998, 2008.

Beach, A.: Retrogressive metamorphic processes in shear zones with special reference to the Lewisian complex, J. Struct. Geol., 2, 257-263, 1980.

Bial, J., Buettner, S. H., Schenk, V., and Appel, P.: The long-term high-temperature history of the central Namaqua Metamorphic Complex: Evidence for a Mesoproterozoic continental back-arc in southern Africa, Precambrian Res., 268, 143-278, 2015.

Billia, M. A., Timms, N. E., Toy, V. G., Hart, R. D., and Prior, D. J.: Grain boundary dissolution porosity in quartzofeldspathic ultramylonites: Implications for permeability enhancement and weakening of mid-crustal shear zones, J. Struct. Geol., 53, 2-14, 2013.

Blanpied, M. L., Lockner, D. A., and Byerlee, J. D.: Frictional slip of granite at hydrothermal conditions, J. Geophys. Res., 100, 13045-13064, 1995.

Blignaut, H. J.: Structural-metamorphic inprint on part of the Namaqua Mobile Belt in South West Africa, Bulletin of the Precambrian Research Unit, 23, University of Cape Town, 197 pp., 1977.

Boulton, C., Moore, D. E., Lockner, D. A., Toy, V. G., Townend, J., and Sutherland, R.: Frictional properties of exhumed fault gouges in DFDP-1 cores, Alpine Fault, New Zealand, Geophys. Res. Lett., 41, 356-362, 2014.

Brodie, K. H. and Rutter, E. H.: The role of transiently fine grained reaction products in syntectonic metamorphism: natural and experimental examples, Can. J. Earth Sci., 24, 554-564, 1987.

Clifford, T. N., Barton, E. S., and Stern, R. A.: U-Pb calendar for Namaqua (Grenville) crustal events in the granulite facies terrane of the O'okiep Copper District of South Africa, J. Petrol., 45, 669-691, 2004.

Cooper, C. M., Lenardic, A., and Moresi, L.: The thermal structure of stable continental lithosphere within a dynamic mantle, Earth Planet. Sc. Lett., 222, 807-817, 2002.

Cornell, D. H., Pettersson, Å., Whitehouse, M. J., and Schersten, A.: A new chronostratigraphic paradigm for the age and tectonic history of the Mesoproterozoic Bushmanland ore district, South Africa, Econo. Geol., 104, 385-404, 2009.

Cox, S. F. and Etheridge, M. A.: Coupled grain-scale dilatancy and mass transfer during deformation at high fluid pressures: exam- ples from Mount Lyell, Tasmania, J. Struct. Geol., 11, 147-162, 1989.

de Ronde, A. A., Stünitz, H., Tullis, J., and Heilbronner, R.: Reaction-induced weakening of plagioclase-olivine composites, Tectonophysics, 409, 85-106, 2005.

Diener, J. F. A.: Low- $P$-high- $T$ metamorphism of the Aggeneys Terrane, Namaqua Metamorphic Complex, South Africa, South African J. Geol., 117, 31-44, 2014.

Diener, J. F. A., White, R. W., and Powell, R.: Granulite facies metamorphism and subsolidus fluid-absent reworking, Strangways Range, Arunta Block, central Australia, J. Metamorph. Geol., 26, 603-622, 2008.

Diener, J. F. A., White, R. W., Link, K., Dreyer, T. S., and Moodley, A.: Clockwise, low-P metamorphism of the Aus granulite terrain, southern Namibia, during the Mesoproterozoic Namaqua Orogeny, Precambrian Res., 224, 629-652, 2013.

Dziggel, A., Diener, J. F. A., Stoltz, N. B., and Kolb, J.: Role of $\mathrm{H}_{2} \mathrm{O}$ in the formation of garnet coronas during near-isobaric cooling of mafic granulites: the Tasiusarsuaq terrane, southern West Greenland, J. Metamorph. Geol., 30, 957-972, 2012.

Etheridge, M. A. and Cooper, J. A.: Rb/Sr isotopic and geochemical evolution of a recrystallized shear (mylonite) zone at Broken Hill, Contributions in Mineral. Petrol., 78, 74-84, 1981.

Etheridge, M. A., Wall, V. J., and Vernon, R. H.: The role of the fluid phase during regional metamorphism and deformation, J. Metamorph. Geology, 1, 205-226, 1983.

Fagereng, A. and Diener, J. F. A.: San Andreas Fault tremor and retrograde metamorphism, Geophys. Res. Lett., 38, L23303, doi:10.1029/2011GL049550, 2011.

Fitz Gerald, J. D., Mancktelow, N. S., Pennacchioni, G., and Kunze, K.: Ultrafine-grained quartz mylonites from high-grade shear zones: Evidence for strong dry middle to lower crust, Geology, 34, 369-372, 2006.

Fliervoet, T. F., White, S. H., and Drury, M. R.: Evidence for dominant grain-boundary sliding deformation in greenschist- and amphibolite-grade polymineralic ultramylonites from the Redbank Deformed Zone, Central Australia, J. Struct. Geol., 19, 1495-1520, 1997.

Fukuda, J. and Okudaira, T.: Grain-size-sensitive creep of plagioclase accompanied by solution-precipitation and mass transfer under mid-crustal conditions, J. Struct. Geol., 51, 61-73, 2013.

Fulton, P. M. and Saffer, D. M.: Potential role of mantle-derived fluids in weakening the San Andreas Fault, J. Geophys. Res., 114, B07408, doi:10.1029/2008JB006087, 2009.

Fusseis, F., Regenauer-Lieb, K., Liu, J., Hough, R. M., and De Carlo, F.: Creep cavitation can establish a dynamic granular fluid pump in ductile shear zones, Nature, 459, 974-977, 2009.

Fyfe, W. S., Price, N. J., and Thompson, A. B.: Fluids in the Earth's Crust, Elsevier, Amsterdam, 1978.

Getsinger, A. J., Hirth, G., Stünitz, H., and Goergen, E. T.: Influence of water on rheology and strain localization in the lower continental crust, Geochem. Geophy. Geosy., 14, 2247-2264, 2013.

Goodwin, L. B. and Tikoff, B.: Competency contrast, kinematics and the development of foliations and lineations in the crust, J. Struct. Geol., 24, 1065-1085, 2002.

Green, E. C. R., White, R. W., Diener, J. F. A., Powell, R., Holland, T. J. B., and Palin, R. M.: Activity-composition relations for the calculation of partial melting equilibria in metabasic rocks, J. Metamorph. Geology, 34, doi:10.1111/jmg.12211, 2016. 
Guiraud, M., Powell, R., and Rebay, G.: $\mathrm{H}_{2} \mathrm{O}$ in metamorphism and unexpected behaviour in the preservation of metamorphic assemblages, J. Metamorph. Geol., 19, 445-454, 2001.

Guzofski, C. A. and Furlong, K. P.: Migration of the Mendocino triple junction and ephemeral crustal deformation: Implications for California Coast Range heat flow, Geophys. Res. Lett., 29, 1012, doi:10.1029/2001GL013614, 2002.

Handy, M. R., Wissing, S., and Streit, L.: Frictional-viscous flow in mylonite with a varied bimineralic composition and its effect on lithospheric strength, Tectonophysics, 303, 175-191, 1999.

Herwegh, M., Linckens, J., Ebert, A., Berger, A., and Brodhag, S. H.: The role of second phases for controlling microstructural evolution in polymineralic rocks: A review, J. Struct. Geol., 33, 1728-1750, 2011.

Hirth, G., Teyssier, C., and Dunlap, W.: An evaluation of quartzite flow laws based on comparisons between experimentally and naturally deformed rocks, Int. J. Earth Sci., 90, 77-87, 2001.

Holland, T. J. B. and Powell, R.: An improved and extended internally consistent thermodynamic dataset for phases of petrological interest, involving a new equation of state for solids, J. Metamorph. Geol., 29, 333-383, 2011.

Holyoke, C. W. and Tullis, J.: Formation and maintenance of shear zones, Geology, 34, 105-108, 2006.

Hubbert, M. K. and Rubey, W. W.: Role of fluid pressure in mechanics of overthrust faulting, Geol. Soc. Am. B., 70, 115-206, 1959.

Hubert-Ferrari, A., Armijo, R., King, G., Meyer, B., and Barka, A.: Morphology, displacement, and slip rates along the North Anatolian Fault, Turkey, J. Geophys. Res., 107, 2235, doi:10.1029/2001JB000393, 2002.

Imber, J., Holdsworth, R. E., Butler, C. A., and Lloyd, G. E.: Fault zone weakening processes along the reactivated Outer Hebrides Fault Zone, Scotland, J. Geol. Soc. Lond., 154, 105-109, 1997.

Jackson, J. A.: Strength of the continental lithosphere: Time to abandon the jelly sandwich?, GSA Today, 12, 4-10, 2002.

Jackson, M. P. A.: High-grade metamorphism and migmatisation of the Namaqua metamorphic complex around Aus in the southern Namib desert, South West Africa, Bulletin of the Precambrian Research Unit, 18, University of Cape Town, 299 pp., 1976.

Jamtveit, B., Malthe-Soerenssen, A., and Kostenko, O.: Reaction enhanced permeability during retrogressive metamorphism, Earth Planet Sc. Lett., 267, 620-627, 2008.

Kerrich, R., Fyfe, W. S., and Allison, I.: Iron reduction around goldquartz veins, Yellowknife district, Northwest Territories, Canada, Econ. Geol., 72, 657-663, 1977.

Kerrich, R., La Tour, T. E., and Willmore, L.: Fluid participation in deep fault zones: Evidence from geological, geochemical, and ${ }^{18} \mathrm{O} /{ }^{16} \mathrm{O}$ relations, J. Geophys. Res., 89, 4331-4343, 1984.

Kilian, R., Heilbronner, R., and Stünitz, H.: Quartz grain size reduction in a granitoid rock and the transition from dislocation to diffusion creep, J. Struct. Geol., 33, 1265-1284, 2011.

Kirby, S., Wang, K., and Brocher, T.: A possible deep, long-term source for water in the northern San Andreas Fault system: A ghost of Cascadia subduction past?, EOS Transactions (Fall Meeting Supplement), 83, S22B-1038, 2002.

Kirby, S. H.: Rock mechanics observations pertinent to the rheology of the continental lithosphere and the localization of strain along shear zones, Tectonophysics, 119, 1-27, 1985.
Koons, P. O. and Craw, D.: Gold mineralization as a consequence of continental collision: an example from the Southern Alps, New Zealand, Earth Planet. Sc. Lett., 103, 1-9, 1991.

Lambert, C. W.: Granitic melt transport and emplacement along transcurrent shear zones: Case study of the Pofadder Shear Zone in South Africa and Namibia, Master's thesis, University of Stellenbosch, 128 pp., 2013.

Macey, P. H., Minnaar, H., Miller, J. A., Lambert, C. W., Groenwald, C., Diener, J. F. A., Le Roux, P. J., and Frei, D.: The Precambrian geology of the region south of Warmbad from Haib to Velloorsdrift, southern Namibia, Geological Survey of Namibia, Windhoek, 476 pp., 2014.

Mancktelow, N. S.: How ductile are ductile shear zones?, Geology, 34, 345-348, 2006.

Mancktelow, N. S. and Pennacchioni, G.: The control of precursor brittle fracture and fluid-rock interaction on the development of single and paired ductile shear zones, J. Struct. Geol., 27, 645661, 2005.

Mancktelow, N. S., Grujic, D., and Johnson, E.: An SEM study of porosity and grain boundary microstructure in quartz mylonites, Simplon Fault Zone, Central Alps, Contrib. Mineral. Petrol., 131, 71-85, 1998.

McCaig, A. M.: Deep fluid circulation in fault zones, Geology, 16, 867-870, 1988.

McCaig, A. M. and Knipe, R. J.: Mass-transport mechanisms in deforming rocks: Recognition using microstructural and microchemical criteria, Geology, 18, 824-827, 1990.

McCaig, A. M., Wickham, S. M., and Taylor, H. P.: Deep fluid circulation in alpine shear zones, Pyrenees, France: field and oxygen isotope studies, Contrib. Mineral. Petrol., 106, 41-60, 1990.

Melcher, F., Graupner, T., Gäbler, H.-E., Sitnikova, M., HenjesKunst, F., Oberthür, S., Gerdes, A., and Dewaele, S.: Tantalum(niobium-tin) mineralisation in African pegmatites and rare metal granites: Constraints from $\mathrm{Ta}-\mathrm{Nb}$ oxide mineralogy, geochemistry and U-Pb geochronology, Ore Geol. Rev., 64, 667719, 2015.

Menegon, L., Pennacchioni, G., and Stünitz, H.: Nucleation and growth of myrmekite during ductile shear deformation in metagranites, J. Metamorph. Geol., 24, 553-568, 2006.

Menegon, L., Fusseis, F., Stünitz, H., and Xiao, X.: Creep cavitation bands control porosity and fluid flow in lower-crustal shear zones, Geology, 43, 227-230, 2015.

Menzies, C. D., Teagle, D. A. H., Craw, D., Cox, S. C., Boyce, A. J., Barrie, D., and Roberts, S.: Incursion of meteoric waters into the ductile regime in an active orogen, Earth Planet. Sc. Lett., 399, 1-13, 2014.

Miller, R. M.: The Geology of Namibia, vol. 2, Geological Survey of Namibia, Windhoek, 2008.

Moecher, D. P. and Steltenpohl, M. G.: Direct calculation of rupture depth for an exhumed paleoseismogenic fault from mylonitic pseudotachylyte, Geology, 37, 999-1002, 2009.

Moen, H. F. G. and Toogood, D. J.: The geology of the Onseepkans area. Explanation: Sheet 2818, Council for Geoscience, 2007.

Montesi, L. G. J.: Fabric development as the key for forming ductile shear zones and enabling plate tectonics, J. Struct. Geol., 50, 254-266, 2013.

Morrissey, L. J., Hand, M., Raimondo, T., and Kelsey, D. E.: Longlived high-temperature, low-pressure granulite facies metamor- 
phism in the Arunta Region, central Australia, J. Metamorph. Geol., 32, 25-47, 2014.

O'Hara, K.: Fluid flow and volume loss during mylonitization: an origin for phyllonite in an overthrust setting, North Carolina, USA, Tectonophysics, 156, 21-36, 1988.

Oliver, N. H. S.: Review and classification of structural controls on fluid flow during regional metamorphism, J. Metamorph. Geol., 14, 477-492, 1996.

Ozacar, A. A. and Zandt, G.: Crustal structure and seismic anisotropy near the San Andreas Fault at Parkfield, California, Geophys. J. Int., 178, 1098-1104, 2009.

Peach, C. J. and Spiers, C. J.: Influence of crystal plastic deformation on dilatancy and permeability development in synthetic rock salt, Tectonophysics, 256, 101-128, 1996.

Poirier, J. P.: Shear localization and shear instability in materials in the ductile field, J. Struct. Geol., 2, 135-142, 1980.

Powell, R. and Holland, T. J. B.: An internally consistent thermodynamic dataset with uncertainties and correlations: 3 . Application, methods, worked examples and a computer program, J. Metamorph. Geol., 6, 173-204, 1988.

Pryer, L. L.: Microstructures of feldspars from a major crustal thrust zone: the Grenville Front, Ontario, Canada, J. Struct. Geol., 15, 21-36, 1993.

Rebay, G., Powell, R., and Diener, J. F. A.: Calculated phase equilibria for a MORB composition in a $P-T$ range, $450-650^{\circ} \mathrm{C}$ and 18-28 kbar: the stability of eclogite, J. Metamorph. Geol., 28, 635-645, 2010.

Rennie, S. F., Fagereng, Å., and Diener, J. F. A.: Strain distribution within a km-scale, mid-crustal shear zone: The Kuckaus Mylonite Zone, Namibia, J. Struct. Geol., 56, 57-69, 2013.

Rice, J. R.: Fault stress states, pore pressure distributions, and the weakness of the San Andreas fault, in: Fault Mechanics and Transport Properties of Rocks, edited by: Evans, B. and Wong, T., Academic Press, San Diego, 475-503, 1992.

Robb, L. J., Armstrong, R. A., and Waters, D. J.: Nature and duration of mid-crustal granulite facies metamorphism and crustal growth: evidence from single zircon $\mathrm{U}-\mathrm{Pb}$ geochronology in Namaqualand, South Africa, J. Petrol., 40, 1747-1770, 1999.

Rutter, E. H.: The kinetics of rock deformation by pressure solution, Philos. T. R. Soc. Lond., 283, 203-219, 1976.

Rutter, E. H., Holdsworth, R. E., and Knipe, R. J.: The nature and significance of fault zone weakening: an introduction, in: The Nature and Significance of Fault Zone Weakening, edited by: Holdsworth, R. E., Strachan, R. A., Magloughlin, J. F., and Knipe, R. J., vol. 186, of Special Publications, Geol. Soc. Lond., 2001

Rybacki, E. and Dresen, G.: Dislocation and diffusion creep of synthetic anorthite aggregates, J. Geophys. Res., 105, 26017-26036, 2000.

Savage, J. C. and Burford, R. O.: Geodetic determination of relative plate motion in central California, J. Geophys. Res., 78, 832-845, 1973.

Schmid, S. M., Panozzo, R., and Bauer, S.: Simple shear experiments on calcite rocks: rheology and microfabric, J. Struct. Geol., 9, 747-778, 1987.

Scholz, C. H.: The brittle-plastic transition and the depth of seismic faulting, Geol. Rundsch., 77, 319-328, 1988.
Shelly, D. R.: Migrating tremors illuminate complex deformation beneath the seismogenic San Andreas Fault, Nature, 463, 648$652,2010$.

Shelly, D. R. and Hardebeck, J. L.: Precise tremor source locations and amplitude variations along the lower-crustal central San Andreas Fault, Geophys. Res. Lett., 37, L14301, doi:10.1029/2010GL043672, 2010.

Sibson, R. H.: Transient discontinuities in ductile shear zones, J. Struct. Geol., 2, 165-171, 1980.

Spotila, J. A., Niemi, N., Brady, R., House, M. A., Buscher, J., and Oskin, M.: Long-term continental deformation associated with transpressive plate motion: The San Andreas fault, Geology, 35, 967-970, 2007.

Spruzeniece, L. and Piazolo, S.: Strain localization in brittle-ductile shear zones: fluid-abundant vs. fluid-limited conditions (an example from Wyangala area, Australia), Solid Earth, 6, 881-901, doi:10.5194/se-6-881-2015, 2015.

Tenczer, V., Powell, R., and Stüwe, K.: Evolution of $\mathrm{H}_{2} \mathrm{O}$ content in a polymetamorphic terrane: the Plattengneiss Shear Zone (Koralpe, Austria), J. Metamorph. Geol., 24, 281-295, 2006.

Till, A. B., Roeske, S. M., Sample, J. C., and Foster, D. A.: Exhumation Associated with Continental Strike-Slip Fault Systems, vol. 434 of Special Papers, Geol. Soc. Am., 2007.

Toogood, D. J.: Structural and metamorphic evolution of a gneiss terrain in the Namaqua Belt near Onseepkans, South West Africa, Bulletin of the Precambrian Research Unit, 19, University of Cape Town, 220 pp., 1976.

Wannamaker, P. E., Jiracek, G. R., Stodt, J. A., Caldwell, T. G., Gonzalez, V. M., McKnight, J. D., and Porter, A. D.: Fluid generation and pathways beneath an active compressional orogen, the New Zealand Southern Alps, inferred from magnetotelluric data, J. Geophys. Res., 107, ETG 6-1-ETG 6-20, doi:10.1029/2001JB000186, 2002.

Waters, D. J.: Metamorphic history of sapphirine-bearing and related magnesian gneisses from Namaqualand, South Africa, J. Petrol., 27, 541-565, 1986.

Waters, D. J.: Partial melting and the formation of granulite facies mineral assemblages in Namaqualand, South Africa, J. Metamorph. Geol., 6, 387-404, 1988.

Waters, D. J. and Whales, C. J.: Dehydration melting and the granulite transition in metapelites from southern Namaqualand, South Africa, Contrib. Mineral. Petrol., 88, 269-275, 1984.

Wech, A. G., Boese, C. M., Stern, T. A., and Townend, J.: Tectonic tremor and deep slow slip on the Alpine Fault, Geophys. Res. Lett., 39, L10303, doi:10.1029/2012GL051751, 2012.

White, J. C.: Paradoxical pseudotachylyte - fault melt outside the seismogenic zone, J. Struct. Geol., 38, 11-20, 2012.

White, R. W. and Powell, R.: Melt loss and the preservation of granulite facies mineral assemblages, J. Metamor.ph Geol., 20, 621632, 2002.

White, R. W., Powell, R., Holland, T. J. B., Johnson, T. E., and Green, E. C. R.: New mineral activity-composition relations for thermodynamic calculations in metapelitic systems, J. Metamorph. Geol., 32, 261-286, 2014.

White, S.: Strain and the development of deformation features in quartz tectonites, Philos. T. R. Soc. Lond., 283A, 69-86, 1976.

White, S. H. and Knipe, R. J.: Transformation and reaction enhanced ductility in rocks, J. Geol. Soc. Lond., 135, 513-516, 1978. 
Wintsch, R. P., Christoffersen, R., and Kronenberg, A. K.: FluidRock Reaction Weakening of Fault Zones, J. Geophys. Res.-Sol. Ea., 100, 13021-13032, 1995.

Wittlinger, G., Tapponnier, P., Poupinet, G., Mei, J., Danian, S., and Herquel, G. and Masson, F.: Tomographic evidence for localized lithospheric shear along the Altyn Tagh Fault, Science, 282, 74 76, 1998.

Worley, B. A. and Wilson, C. J. L.: Deformation partitioning and foliation reactivation during transpressional orogenisis, an example from the Central Longmen Shan, China, J. Struct. Geol., 18, 395-411, 1996.
Zoback, M. D., Prescott, W. H., and Krueger, S. W.: Evidence for lower crustal ductile strain localization in southern New York, Nature, 317, 705-707, 1985. 